\title{
민주적 거버넌스와 경제발전
}

\author{
김 달 현 경희대학교 국제대학원 객원교수
}

\section{목 차}

I. 서 론

II. 거버넌스체계와 제도의 중요성

III. 민주주의와 경제발전

IV. 민주적 거버넌스 지표의 분석

V. 요약 및 결론

\section{I. 서 론}

경제발전은 민주주의를 요구하며 민주주의는 다시 경제적 번영을 가져오는가에 관한 문제는 오랫 동안 논쟁의 대상이 되어온 미해결의 주제이다. 민주주의는 세계적으로 확산되어 오고 있지만 최근 에는 무한한 경제력을 가진 중국과 러시아로부터 도전을 받고 있다. 남미에서는 새로운 좌파가 민주 주의에 대한 견해를 재정립하고 있다. 2008-2009년의 세계적 경제위기는 자유 시장 경제모델의 타 당성을 의심하게 되었고 강력한 정부역할을 주장하는 학자도 등장하였다. 현재의 상황에서는 민주주 의나 시장경제가 경제적인 목적을 달성하는데 필요하지 않으며 오히려 권위주의적 모델이 더 적합하 다고 주장하는 일부 견해도 있다.

일부학자들은 민주주의가 경제성장에 적극적인 영향을 미친다는 견해가 있는가 하면 다른 학자들 은 권위주의적 정부가 더 높은 성장률을 보여준다는 견해를 피력하고 있다. Seymour M. Lipset, Robert Dahl, Samuel Huntington은 경제성장과 민주주의 간에는 연관성을 가지고 있다고 주장하 고 있다. 또한 Przeworski는 연관성은 있지만 경제성장은 다만 민주주의의 안정에만 영향을 미친다 는 것이다. 이와 반대되는 견해를 주장하는 학자인 Mancur Olson은 민주주의는 낮은 경제성장을 줄 가능성이 있다고 한다. 왜냐하면 만주주의는 효율적인 자원배분을 저해하는 이익집단의 영향을 많이 받기 때문이다. Lipset의 독창적인 연구 이후 많은 학자들은 경제발전과 민주주의간의 관계에 대하여 긍정도 하고 부정도 하고 다시 긍정을 반복해오고 있는 실정이다. 
본 논문은 제도적 접근방법을 따라 거버넌스와 발전의 관계를 논의하려고 한다. 거버넌스 제도는 민주주의와 경제발전에 영향을 주며 양자는 상호작용을 한다는 것이다. 장기적인 정치적 및 경제적 발전과정에서는 거버넌스 제도의 개혁이 적극적인 장기효과를 초래하는 초석이라고 생각한다. 따라 서 여기에서는 민주적 거버넌스제도, 시장경제와 경제발전을 중심으로 논의하려고 한다. 즉 지속가 능한 발전은 민주적 거버넌스의 기능적 제도 없이는 불가능한 것이다. 즉 부분분석의 접근방법을 주 로 사용하였지만 끝에서는 일반분석의 입장에서 각 변수 간에 상호작용도 논의하였다. 본 논문의 구 성은 서론 다음에 II에서는 양호한 거버넌스의 체계 와 민주적 거버넌스 및 제도의 중요성을 논하고 III에서는 민주주의, 양호한 거버넌스와 지속적인 경제발전을 위한 제도의 역할을 다룬다. 그러나 일 반분석의 입장에서 개발전략의 우선순위에서는 거버넌스제도 이외에도 다른 변수의 사용가능성도 논 하였다. IV에서는 민주적 거버넌스 지표를 성공국가와 실패국가의 사례로 나누어 비교분석을 한다. $\mathrm{V}$ 에서는 요약과 결론으로 끝을 맺으려고 한다.

\section{II. 거버넌스의 체계와 제도의 중요성}

\section{1. 거버넌스의 개념 및 형태}

\section{(1) 거버넌스의 정의}

거버넌스의 정의는 아직 국제적으로 합의된 것은 없으나, 일반적으로 거버넌스는 일국의 정치, 경 제 및 사회적 자원의 배분과 관리와 관련된 총체적인 구조를 의미한다. 또한 거버넌스는 사회전반에 걸쳐 영향력을 행사하는 광범위한 개념으로 여타 분야의 개발과 투자에 우선하여 추진해 나가야하는 개발의 기본과제이다. 거버넌스의 정의는 양자 및 다자기구의 관점과 관심분야에 따라 다양하다. (김 달현. 2011, p. 121)

〈그림 1〉은 역사, 정치, 경제, 사회 및 문화적 제요인이 거버넌스의 각 영역과 개발결과에 순차적 으로 미치는 파급과정을 나타낸 것이다. 이 그림은 이러한 복잡한 관계를 요약한 것이다. 1) 즉 (그림 $1>$ 은 거버넌스와 발전의 분석체계에서 보는바와 같이 거버넌스는 정치, 경제, 사회 및 문화 등 각 방 면의 발전에 지대한 영향을 미치고 있다.

개발정책에 있어서 거버넌스의 역할에 두 가지 사항을 언급할 필요가 있다. (i) 거버넌스는 정의한 그자체로 보나 평등하고 지속적인 발전을 달성하는 수단으로서 매우 중요하다는 것이다. (ii) 거버넌 스가 무엇이며 어떻게 이를 민주주의와 차별화하며 어떻게 이것이 발전 및 진보와 연계되는가를 밝

1) 거버넌스와 발전의 관계를 다른 시각에서 보여준 문헌의 그림을 참조할 것. Noha El-Mikawy and Ingvild, Understanding and Programming for Linkage: Democratic Governance and Development, 2009, p. 4 
히는데 일치된 명확한 견해가 없다. 따라서 거버넌스의 정의는 다양하게 내리고 있지만 거버넌스가 어떻게 권한을 행사하고 규제한다는 대해서는 의견의 일치를 보고 있다.

\section{(2) 정치적 거버넌스}

정치 거버넌스(political governance)는 합법적이고 권위 있는 국가의 정치적 의사결정과 정책을 수립하는 과정을 말한다. 민주국가는 권력이 분산되어 상호견제하며 시민들은 지도자와 대표자를 선 출하는데 참여하게 된다. 정치적 거버넌스는 정부의 합법성, 정부능력, 정부책임, 법치와 인권 등을 포함하고 있다. 정치 거버넌스는 민주주의에 영향을 미친다.

\section{(3) 경제적 거버넌스}

경제 거버넌스(economic governance)는 일국의 경제활동(국내)과 타국경제와의 관계에 영향을 주 는 의사결정과정을 말한다. 이는 평등, 빈곤 및 생활의 질에 대한 중요한 의미를 담고 있다. 경제적 거버넌스는 공공부문관리, 법치, 계약 및 재산권, 조직상의 책임, 투명성과 정보의 자유 등을 포함하 고 있다. 경제 거버넌스는 시장경제를 통하여 경제성장 및 발전에 영향을 미친다.

\section{〈그림 1〉거버넌스와 발전의 분석 체계}

\begin{tabular}{|c|c|c|}
\hline 결정요인 $\quad \rightarrow$ & 거버넌스 영역 & 발전 결과 \\
\hline $\begin{array}{l}\text { 역사적배경 } \\
\text { 전 정권 } \\
\text { 사회 문화적 배경 } \\
\text { 경제제도 } \\
\text { 국제환경 }\end{array}$ & $\begin{array}{l}\text { 시민사회 } \\
\text { 정치사회 } \\
\text { 정부 } \\
\text { 관료체계 } \\
\text { 경제사회 } \\
\text { 사법제도 }\end{array}$ & $\begin{array}{l}\text { 정치적 자유와 귄리 } \\
\text { 인간안보와 후생 } \\
\text { 경제성장 } \\
\text { 인간자본(보건 및 교육) } \\
\text { 신뢰와 사회자본 }\end{array}$ \\
\hline
\end{tabular}

자료 : ODI(2006) Governance, Development and Aid Effectiveness: A Quick Guide to Complex Relationships, Briefing Paper

\section{(4) 민주적 거버넌스}

민주적 거버넌스(democratic governance)는 책임성, 투명성, 포괄성, 대응성을 지닌 효과적이고 유능한 국가를 만드는 의사결정과정을 말한다. 따라서 모든 국가는 선거 및 입법제도를 강화하고 사 법과 공공행장의 접근을 개선하며 필요한 국민에게 기본서비스를 공급할 능력을 키워야 한다.

\section{(5) 개발적 거버넌스}

개발적 거버넌스(developmental governance)는 아프리카의 국가들의 재건을 위하여 다양한 사회 
부문(공공부문, 민간부문, 시민사회 개인 등)에서 오는 아프리카 이해당사자들의 의지의 산물이다. 그들은 지방, 전국, 지역, 대륙 및 국제적 영역을 포함하고 있다. 그리하여 이는 과거 및 현재를 재검 하고 공통가치의 유산을 바탕으로 아프리카의 비젼을 확립하는데 있다. 아프리카는 자신의 매트 (mat)를 짜고 더 이상 다른 사람의 매트에서 자지 않겠다는 것이다. 개발적 거버넌스의 기본구상은 (i) 민주주의와 인권, (ii) 경제 및 사회 발전, (iii) 아프리카의 평화, 인간 안보와 지속적 발전을 근간 으로 하고 있다.

\section{2. 양호한 거버넌스의 체계}

\section{(1) 양호한 거버넌스의 개념}

오늘날 거버넌스는 발전과정에 있어서 중심적 지위를 차지하고 있으므로 발전 전략에 포함시켜야 할 중요한 요소로 간주되고 있다. 따라서 양호한 거버넌스(good governance)는 정부역할의 패러다 임 이동을 상징하는 용어이다(Holz \& Kim, 2002). 즉, 양호한 거버넌스는 집단적인 제 문제에 대응 하여 자원의 배분과 관리를 다루는 것으로 참여, 투명성, 책임성, 법치, 효과성 및 평등의 원칙을 준 수해야 한다.

$\mathrm{UNDP}$ 는 양호한 거버넌스는 개도국의 성공적인 발전을 위한 본질로, 하나의 보편적인 원칙을 말 하며 다음의 9 개의 핵심적 원칙을 지니고 있다고 보고 있다. 각 원칙은 상술한 거버넌스의 각 분야에 적용되는 것이다(UNDP, 1997). 양호한 거버넌스는 참여, 법치, 투명, 대응, 여론에 의한 합의, 평등, 효과와 효율, 책임 및 전략적 비젼 등을 포함하고 있다. 최소한 양호한 거버넌스는 독립적인 사법제 도 하에서 불편부당하게 집행하는 공평한 법제도를 요구한다. 따라서 그들의 결정과 집행은 투명하 고 규정과 규칙에 따라 집행해야 한다. 책임성은 투명성과 법치 없이는 수행할 수 없기 때문에 책임 성은 양호한 거버넌스의 주요 요건이다. 양호한 거버넌스는 공평한 법적 체계를 요구한다. 이러한 양 호한 거버넌스의 원칙은 정부는 물론 민간부문과 시민사회도 모두 준수해야 할 사항이다. (Sharma, 2007, pp.31-33) 좋은 제도만이 양호한 거버넌스를 얻을 수 있으며 제도는 장단기 적으로 모두 중요 한 것이다. 왜냐하면 제도는 한사회의 유인제도(incentive system)를 형성하며 경제적 실적의 기초 적 결정요인이다. 결국 양호한 거버넌스는 제도적 질에 따라 좌우되는 것이라고 볼 수 있다. 제도 구 축과 민주주의는 양호한 거버넌스와 경제발전을 위하여 필요 불가결한 것이다.

끝으로 발전에 있어서 경제적 및 정치적 거버넌스 간에 대립관계를 볼 수 있다. 즉, 전자는 권력의 보유자는 어떻게 생산요소, 금융 및 시장을 관리/규제하는가에 초점을 두는 반면에 후자는 누가 권 력을 장악하며 어떻게, 왜, 어느 정도 힘과 집행을 합법적으로 독점하는가에 초점을 두고 있다. 그러 나 사실상, 경제적 거버넌스와 정치적 거버넌스는 보완적인 면도 있다. 예컨대, 법치(rule of law)는 동시에 권력보유자를 견제하고 시장기능을 가능하게 한다. 그리하여 법치는 경제자산, 시민 권리와 
정치 권리를 모두 보호해 준다.

\section{(2) 양호한 거버넌스의 체계}

거버넌스는 (i) 민주적 거버넌스와 권위주의적 거버넌스로도 분류할 수 있다. 어떠한 정치, 경제제 도하에서도 거버넌스는 존재하며 민주주의 하에서도 양호한 거버넌스와 취약한 거버넌스를 발견할 수 있다. 양호한 거버넌스의 중요한 축이 민주적 거버넌스 일뿐이다. (ii) 양호한 거버넌스는 효과적 인 법적 및 규제적 체계를 갖추어 장기적으로 민주주의와 경제발전에 기여한다는 것이다. 반면에 취 약한 거버넌스는 부적합한 법적 및 규제적 체계(책임성과 법치의 결여, 재산권, 계약이행 등), 약한 시민권의 보호, 취약한 사회서비스의 공급 등을 의미하며 이는 일국의 민주주의와 경제발전을 저해 한다. (iii) 양호한 거버넌스는 정치적 거버넌스와 경제적 거버넌스로 대별할 수 있다. 정치적 거버넌 스는 정부의 합법성, 정부능력, 정부책임, 법치와 인권 등을 포함하고 있다. 또한 경제적 거버넌스 는 공공부문관리, 법치, 계약 및 재산권, 조직상의 책임, 투명성과 정보의 자유 등을 포함하고 있다. (〈그림 2〉 참조) 결국 양호한 거버넌스는 정치적 측면과 경제적 측면이 있어 정치적 측면은 민주주의 에, 경제적 측면은 경제발전에 각각 영향을 미친다. 최근에는 정치적 거버넌스와 경제적 거버넌스는 지속적 인간개발에 지대한 영향을 미친다는데 의견의 일치를 보고 있다. 그러므로 두 측면은 상호작 용을 미치는 것이다. 물론 권위주의적 거버넌스 제도도 비민주의체제와 경제발전에 영향을 미치는 것이다.

\section{3. 민주적 거버넌스}

많은 국가들의 횡단분석(cross section analysis)을 사용한 경험적 연구에 의하면 민주주의를 개선 하는 거버넌스는 경제성장을 가져온다는 것을 실증하였다. 더욱이 정치적 자유(민주적 거버넌스)는 경제성장에 적극적 효과를 초래한다는 실증적 연구를 보여주었다. 이러한 민주주의를 유지하기위해 서는 우선 민주적 거버넌스가 확립되어야 한다. 사실상 UNDP는 민주주의와 거버넌스를 합성하여 “민주적 거버넌스"(democratic governance)라고 규정하였다. 민주적 거버넌스는 책임성, 투명성, 포 괄성, 및 대응성을 갖춘 효과적이고 능력 있는 국가를 건설하는 데 있다. 각국은 선거 및 입법제도를 강화하며 법과 공공행정을 개선하고 필요한 국민에게 기본서비스를 제공하는 보다 큰 능력을 배양해 야 한다.

민주적 거버넌스는 권위주의적 정부에 비하여 세 가지 장점을 가지고 있다. (i) 민주주의는 분쟁을 잘 관리할 수 있고 폭력적인 정치적 변화를 피할 수 있다. 


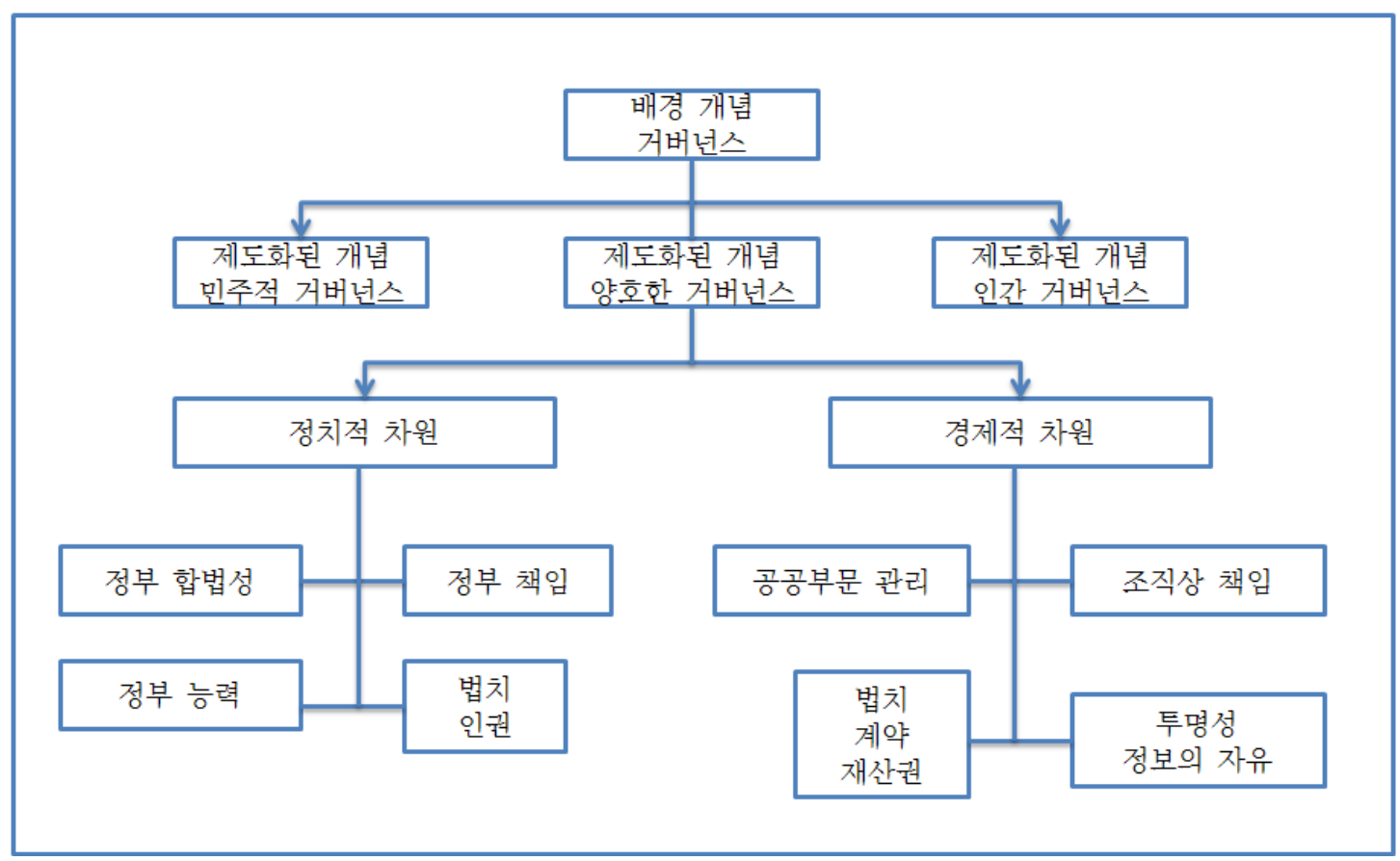

자료: Noha El-Mikawy and Ingvild, Understanding and Programming for Linkage: Democratic Governance and Development, Oslo Governance Center, 2009, p. 4

왜냐하면 민주주의는 국민들에게 정치과정에 참여하는 기회를 주기 때문이다. (ii) 민주주의는 인 간생존에 대한 위협을 더 잘 피할 수 있기 때문이다. 왜냐하면 반대당에 의하여 견제를 받고 공공정 책에 대한 면책특권이 있으며 선거에 의한 공직으로부터의 추방이 두렵기 때문이다. (iii) 민주주의는 사회발전문제에 대한 더 많은 관심( 보건, 여성과 소외 계층의 권리 등)을 가지게 한다. UNDP의 민 주적 거버넌스의 특성은 경제적, 정치적, 법적, 사회적, 문화적인 특성을 포함한 것이다.

민주적 거버넌스는 경제발전에도 필요불가결의 요인이다. 경제발전은 국가의 총체적 부(wealth) 를 증대하고 빈곤감소의 잠재력을 증대시키며 다른 사회문제도 해결해 준다. 그러나 역사는 경제성 장이 이루어진 만큼 인간개발의 발전을 수반하지 못한다는 사실을 보여 주고 있다. 그 대신에 경제성 장은 소득불평등, 높은 실업, 민주주의 약화, 문화 정체성의 상실, 미래세대가 필요한 자원의 과대소 비 등의 희생의 대가로 얻어지는 것이다. (World Bank, 2009, Chapter 1) 따라서 이러한 성장은 오 래 지속될 수 없는 것이다.

지속적인 경제성장은 특히 모든 수준의 결정에 있어서 보다 높은 수준의 민주주의와 동일한 인간 개발의 과실에 의해서만 끊임없이 달성되는 것이다. 민주적 거버넌스의 개념과 민주주의 및 경제발 전의 연계관계를 둘러싸고 맴돌고 있는 충돌과 딜레마에도 불구하고 하나의 사실은 엄연히 그대로 있다. 즉 민주적 거버넌스를 달성하는 핵심은 적절한 제도를 구축하는 것이다. 제도 구축(institution 
building)은 경제발전의 한 요소이며 제도 구축은 역량강화(capacity development)를 전제로 한다.

$\mathrm{UNDP}$ 는 민주적 거버넌스를 개선하기 위하여 다음의 네 개 분야에 걸쳐 개도국을 지원하고 있다. 즉, (i) 정치적 결정에 참여하는 국민의 기회 확대, (ii) 민주제도를 더 책임성 있고 국민에게 순응하 도록 만들고 국민의회, 공공행정과 법치에 대한 지원, (iii) 민주적 거버넌스의 원칙을 확대할 것(특 히 부패방지, 인권, 여권의 강화와 균등한 기회 등), (iv) 개도국 주도의 민주적 거버넌스의 평가지원 등을 들 수 있다. 이러한 노력은 개도국의 민주주의 신장에 크게 기여한다.

$\mathrm{UNDP}$ 가 민주적 거버넌스(democratic governance)를 육성하기 위하여 적극적인 활동을 하는 이 유를 쉽게 이해할 수 있다. ${ }^{2)}$ 민주주의 하의 시장경제가 많은 지지를 받고 있으며 민주적 거버넌스 는 경제성장의 주요 결정요인이지만 제도적 질의 개선과 역량강화를 통해서만 달성할 수 있는 것이 다. (김달현, 2011, p. 131)

민주적 거버넌스는 유인제도(incentive), 재화, 자본, 노동, 창의력(ideas)과 기술 등을 관리하며 가장 중요한 제도는 재산권, 법치와 책임성을 보장하는데 있다. 왜냐하면 이들은 투자와 성장을 위한 사업 환경조성의 초석이 되기 때문이다. 결론적으로 민주적 거버넌스 제도는 지속적인 경제발전과 높은 민주주의를 위한 일국의 발전을 좌우하는 것이다. (UNDP, 2011, Democratic Governance 참조)

\section{4. 제도의 중요성}

\section{(1) 제도(institution)}

제도는 하나의 합의된 규범으로 개인의 행동을 안내하는 게임의 규칙(rule of game), 행동강령 내 지 가이드라인을 말한다. 제도는 사회, 정치 및 경제의 과정을 통하여 발전을 구체화시키는 것이다. 이러한 제도 중에서 공식적 제도는 헌법, 각종 법규, 재산권 등을 말하며 공식적인 제도는 단시일 내 에 변경할 수 있다. 이러한 공식적 제도는 본질적으로 합법성을 제공한다. 이에 반하여 비공식적 제 도는 사회적 관습, 행동규범, 자체적인 행동강령 등을 말하며 비공식적인 제도는 매우 점진적으로 변화하게 됨으로 각국의 역사, 정치, 경제, 제도, 전통 및 관습, 문화 등에 따라 상이하다. (North, 1990; Klein, 1998)

\section{(2) 제도 발전(institutional development)}

제도발전에 관한 정의는 아직 합의된 정의가 없는 실정이다. 제도발전은 공식적 및 비공식적 제도 의 분석, 영향 및 수행에 관한 과정을 개발하는 것을 말한다. 이러한 제도들은 목표 집단이나 조직의 행위를 지배하며 의도하는 목표를 달성하는 것과 깊은 관련이 있다. 이는 고위 정치가들, 중요 주체

2) 최저개발국의 민주적 거버넌스의 도전을 더 보기 위해서는 UNDP(2006) Governance for the Future: Democracy and Development in the Least Developed Countries, Chapter 1 참조. 
자 들과 이해당사자들의 지원과 참여에 따라 좌우되기도 한다. 그러나 광의로는 제도발전에는 새로 운 제도를 만드는(제도 구축/설립)경우와 기존제도를 개선하는(제도개혁) 경우가 있다. 그러나 제도 발전은 제도개혁과 동의어로 사용되는 경우가 많다. 제도적 발전(institutional development)은 최종 사용자와 고객에게 효과적인 서비스를 제공하기 위하여 정부, 민간 및 시민단체의 실적을 향상시키 기 위하여 지원을 해주어야 한다. 또한 제도발전은 다른 주체와 이해당사들이 제도적 장치를 통하여 정책과 의사결정과정을 협의하고 영향을 미치는 범위를 규정하기도 한다. (김달현, 2010, p.41)

\section{(3) 제도의 중요성}

전통적인 경제발전이론은 노동, 물적 및 인적 자본형성과 기술적 변화와 같은 요소에 중점을 두고 제도는 주어진 것으로 가정하였다. 이러한 이론들은 왜 일부 개도국이 다른 개도국보다 더 빨리 성장 하는가를 완전히 설명하지 못한다는 것이다. 그리하여 신제도경제학파에서는 제도는 경제발전에 있 어서 중요한 역할을 한다는 것이다. 규칙과 수행주체가 어떻게 생산요소를 구입하고 이를 어떻게 공 급하며 나아가 어떻게 사용/교환하는가를 결정한다는 것이다. 그들은 법의 규칙, 민주적 거버넌스, 경제정책과 경제성장간에 연결고리의 역할을 한다는 것이다. (Mitchell, 2011, pp. 8-9) 즉, 거버넌스 제도는 민주주의와 경제발전에 지대한 영향을 미친다.

\section{III. 민주주의와 경제발전}

\section{1. 민주주의와 양호한 거버넌스}

많은 사람들은 민주주의정부의 수립이 민주적 제도와 절차의 통합을 즉각적으로 동반하는 것으로 생각하나 그것은 잘못된 생각이다. 각국의 비교연구에 의하면 행정적 및 관료적 문화와 전통과 밀착 된 낡은 체제는 변화하기가 힘든 것이다. 특히 민주화과정은 과거와 단절된 것은 아니다. 민주적인 통합과정은 시간이 걸리며 힘든 것이다. 따라서 양호한 거버넌스를 확립하는데 는 시간이 소요되며 양호한 거버넌스가 이루어지면 그때야 진정한 민주주의를 기대할 수 있다.

민주주의의 기능을 위하여 중요한 제도와 규범이 확립되기 전에 민주주의를 다만 선거와 다수결 원칙만으로 규정하는 것은 잘 못된 것이다. 정치제도 내에 민주적 규범과 가치의 민주적 통합, 제도 화 및 정상화가 선행되어야 한다. 그렇지 않으면 진정한 민주주의를 기대할 수 없다. 즉, 반 자유민 주주의(illiberal democracy), 대리 민주주의(delegative democracy) 또는 혼합 정부(hybrid regime) 등으로 변형될 가능성이 많다. Fareed Zakaria에 의하면 표면적으로 민주주의는 번창하지만 자유는 없다는 것이다. 
민주주의의 사회는 언론, 출판, 집회 및 결사의 자유, 자유선거를 통한 의회제도 및 소비와 직업선 택의 자유를 가지고 있다. 이러한 제도를 통하여 국민은 의사결정에 참여하게 된다. 결국 민주주의를 통하여 많은 편익(교육, 보건 및 기타 공공재)을 받게 된다. 민주사회 하에서는 권력을 유지하기 위 해서는 정부는 사회적 요구에 순응해야 한다. UNDP가 민주적 거버넌스(democratic governance)를 주창하고 이를 위하여 적극적인 활동을 하는 이유가 바로 여기에 있다.

민주주의는 인간개발3)과 빈곤감축을 모두 치유할 수는 없다 해도 다른 정부제도 보다 이러한 목 표를 달성하는데 보다 많은 잠재력을 가지고 있다. 민주주의는 빈자와 약자에게 기회를 주고 능력을 배양시켜 준다. 그러므로 민주주의는 본질적으로 인간개발의 가치를 가지고 있다. 더욱이 안정된 민 주주의는 빈곤수준을 낮추어 주며 바꾸어 말하면 국민의 빈곤상태를 지속시키는 민주주의는 장수할 수가 없다. 양호한 거버넌스는 다음과 같은 기능을 하고 있다. (i) 성장과 고용을 위한 환경조성, (ii) (접근, 질 및 가격을 감안한) 사회서비스 공급, (iii) (접근, 질, 가격을 감안한) 안전과 법치와 (iv) 세 계화의 관리와 지속적 인간개발에 미치는 효과 등을 열거 할 수 있다. 민주주의는 양호한 거버넌스가 바탕이 되고 있다.

거버넌스 체계는 민주주의 국가와 권위주의적인 국가에서 모두 존재하는 것이다. 다만 어떠한 정 치제도하의 거버넌스가 우월성을 가지고 있는가가 문제이다. 역사적으로 보면, 정치적 민주주의와 시장경제하의 거버넌스로 발전한 국가(영국 및 미국)도 있는 반면 권위주의적 시장경제하의 거버넌 스로 발전한 국가(한국, 대만 및 싱가포르)도 있다. 또한 정치적으로 일당 독재와 사회주의 경제하 의 거버넌스(구소련연방과 개혁개방 전 중국)나 일당독재와 사회주의 시장경제하의 거버넌스(개방이 후 중국 및 베트남)로 발전한 국가들도 있다.

요컨대 민주주의는 선거와 다수결원칙으로만 볼 수 없으며 민주주의가 제대로 기능하는데 필요한 거버넌스 제도와 규범이 확립되기 전에는 진정한 민주주의는 기대할 수 없다. 위에서 논의한바와 같 이 양호한 거버넌스를 바탕으로 한 민주주의와 시장경제는 많은 장점을 지니고 있다. 시장경제의 주 축인 시장촉진적인 거버넌스 ${ }^{4)}$ 는 민주주의의 주축인 양호한 거버넌스와 그 맥을 같이하는 것이다. 즉 민주주의 하에서 시장경제를 말하는 것이다. 양호한 거버넌스는 경제성장의 주요 결정요인이지만 제도적 질의 개선과 역량강화를 통하여 달성할 수 있는 것이다.

\section{2. 민주주의와 경제발전에 관한 세 가지 접근방법}

최근에는 경제학자들도 국가 발전과정에서 양호한 거버넌스와 강력한 제도의 역할을 점진적으로 이해하고 있다(Perkins et al., 2006, pp. 82-84). 아직도 민주주의와 경제발전 간에 인과관계에 관

3) 인간개발에 관해서는 본 논문의 III. 5 (4) 지속 가능한 인간개발을 참조할 것

4) 시장 촉진적 거버넌스에 관해서는 김달현(2011) "거버넌스와 개발", 국제개발협력 이슈, 한국국제협력단, pp.129-130 참조 
해서는 대립적인 견해가 남아있고, 민주주의가 경제성장을 도모한다는 견해에 대해서는 명백한 경험 적 증거가 없다. 또한 아직도 민주주의와 경제발전 간에 인과관계에 대해서는 일치된 견해가 없는 실 정이다. 민주주의와 경제발전 간에 인과관계의 검증, 즉 민주주의의 확대가 경제성장을 가져온다는 명제의 명백한 지지를 제공해 주지 못하고 있다. Barro(1996a)는 민주주의와 경제성장간의 관계성립 은 민주주의가 성장의 다른 요인(인간자본 등)과 연결되어 있다는 결론을 내리고 있다. 그러나 민주 주의는 인간개발을 가져온다는 견해에는 이의가 없다. 민주주의(정치적 자유)가 경제발전에 미치는 효과가 지대하다는 사실은 베를린 장벽이 무너진 후에 폴란드, 헝가리 및 체코공화국에서 엿볼 수 있다.

이상 논의한바와 같이 민주주의와 경제발전의 인과관계에 관해서는 아직 일치된 견해가 없다. 즉, 민주주의와 경제발전 간에는 연관성(긍정적 및 부정적)에 관한 명백한 해답이 없는 실정이다. Carlos Santiso에 의하면 다음의 세 가지 견해로 나누고 있다. (i) 민주주의가 경제발전을 육성한다는 견해, (ii) 경제발전이 민주주의를 촉진시킨다는 견해, (iii) 두 가지 견해는 상호의존적이라는 견해 등을 들 수 있다.

\section{(1) 민주주의 우선의 견해}

이 견해는 민주주의가 경제발전을 초래한다는 것으로 민주주의는 경제발전을 촉진하는 독립적인 변수로 보고 있다. 많은 학자들은 민주주의가 경제발전을 촉진한다는 것이다. (Branco, 2006, p. 3). (i) 일반적으로 민주주의는 경제성장을 육성한다는 것이다. 왜냐하면 민주주의는 단기 및 중기적으 로 보다 큰 거시 경제적 안정과 외생적인 충격을 쉽게 관리해 주고 있다.(Rodrik, 1997) (ii) 민주주 의는 국민의 기업가 정신을 촉진한다고 한다. (Goldsmit, 1995) (iii) 민주주의는 권위주의정부 보다 재산권을 더 효과적으로 보호해 준다.(Olson, 1993; North, 2003) (iv) 민주주의는 분쟁의 평화적 관 리를 위해서는 강력한 도구라는 것이다. 특히 아프리카의 내전과 관련된 경우가 많다. (Paster와 Hilt, 1993) (v) 민주주의는 시장경제발전에 가장 적합한 정치제도이며 시장경제의 기본요소는 재산 권의 보호와 기업의 자유인 것이다. (Fitoussi, 2004) 이와 같이 학자에 따라 민주주의의 경제발전에 미치는 효과에 대하여 달리 설명하고 있다.

결론적으로 민주주의는 민주적 과정을 통하여 시장경제를 선정하며 이 시장경제를 통하여 경제발 전이 이루어진다는 것이다. 물론 민주주의가 경제발전에 적극적인 역할을 한다는 견해에 대하여 반 대이론이 많지만 발전의 개념은 하나의 혼합물인 이상 민주주의의 선택 이외에 다른 선택의 여지가 없는 것이다. 결국 민주주의와 경제발전 간에 상호작용을 한다고 볼 때 민주주의는 발전의 본질적 부 분이 되어야 한다. 따라서 민주주의는 발전과 연결되게 된다.

\section{(2) 경제발전 우선의 견해}

이 견해는 경제발전이 민주주의를 초래한다는 것으로 경제발전이 독립변수이고 민주주의가 종속 
변수로 간주한다는 것이다. (i) Robert Kaplan에 의하면 민주주의를 이루기 이전에 많은 전제조건이 충족되어야 한다는 것이다. 예컨대 일정한 수준의 고용, 경제안정과 시민의 평화 등을 예시하고 있 다. 그에 의하면 우선적으로 경제발전이 민주주의를 지탱할 수 있는 기회를 확대할 수 있다는 것이 다. (ii) Barrington Moore와 Martin S. Lipset는 경제발전은 지속적인 민주주의를 위한 필요조건을 제공한다고 주장하고 있다. (Lipset, 1963; Leftwitch, 1994) 이 논의는 유럽의 대국의 역사를 바탕으 로 하고 있다. 민주주의는 높은 수준의 문자 해독율, 통신과 교육, 중산층의 출현과 시민사회 등을 요건으로 한다는 것이다. (iii) Adam Przeworski는 그의 저서 “자본주의와 발전"에서 경제성장과 발 전은 안정된 민주주의를 위해 필요한 것이다. 그의 결론은 통계시계열 자료를 사용하여 도출한 것이 다. 그러나 그는 경제발전은 민주주의에로의 이행을 보장하지는 않는다고 경고하고 있다. 그는 이러 한 맥락에서 볼 때 일국의 역사가 문제시 된다고 논하고 있다.

\section{(3) 양견해의 혼합}

이 견해는 정치적 및 경제발전은 상호의존적인 것으로 인위적으로 양분하거나 또는 우선순위(시계 열화)를 결정해서는 안 된다는 것이다. 종합적인 견지에서 볼 때 한 국가의 경제발전과 민주주의 간 에는 상호작용을 하게 된다. ${ }^{5)}$ 종합적인 입장에서볼때 민주주의와 경제발전도 상호간에 영향을 미친 다고 보아야 하는 것이다.

\section{3. 민주주의와 경제발전}

\section{(1) 민주주의 및 권위주의와 경제발전}

\section{1) 민주주의와 경제발전}

오늘날 민주주의는 보편적인 정치제도로 정부의 이상적인 제도로 간주하고 있다. 자유민주주의는 공개적이고 자유로운 제도적 장치를 통하여 국민이 선출한 정부형태이다. Robert Dahl에 의하면 진정한 대표적 민주정부는 다음과 같은 원칙에 입각해야 한다는 것이다. 즉, (i) 인기 있는 주권, (ii) 경쟁적 인 정치참여와 대표성, (iii) 독립적인 사법제도, (iv) 자유롭고 공평하고 규칙적인 선거, (v) 보편적 인 참정권, (vi) 표현과 양심의 자유, (vii) 정치집회를 형성하고 정치계에서 참여할 보편적 권한, (viii) 포괄적인 시민권, (ix) 헌법과 법치의 준수 등을 갖추어야 한다. (Sharma, 2007, p. 36) 더욱이 권위주의적 정부와는 달리 민주주의는 개인 및 집단적 자유와 아울러 보다 좋은 장기적인 재산권의 보호를 제공해 준다.

5) 앞의 두 견해 (1)과 (2)는 부분분석의 입장에서 민주주의와 경제발전을 분석한 것이고 (3)은 일반분석의 입장에서 두변 수간에 상호작용을 본 것이다. 때로는 부분 분석이 인과관계를 더 뚜렷이 밝힐 때도 있다. 
민주주의는 그의 법적 및 규제적 체계 하에서 생산, 유통, 분배 및 소비에 이르기까지 자유로운 경 제활동을 모두 보장해주는 것이다. 특히 민주주의는 소비선택의 자유, 직업선택의 자유와 자유로운 기업 활동 등을 통하여 시장경제를 육성하고 나아가 경제발전을 지원해 주는 것이다. 다시 말하면 민 주주의는 시장경제를 통하여 경제발전을 촉진시켜 주는 것이다. 따라서 민주주의, 시장경제와 경제 발전은 서로 연관 관계를 맺고 있다. 그러나 개도국은 대체로 민주주의와 시장경제가 미숙한 단계에 있고 시장경제를 지원하는 제도적 장치가 미비하여 선진국과 같은 이상적인 시장의 효율성을 기대하 기 힘들다. ${ }^{6)}$ 정치적 안정과 법치가 존재하지 않는다면 시장경제는 효과적으로 기능을 발휘할 수 없 는 것이다. 민주주의정부는 시장경제를 위하여 절대 필요한 것이다. 왜냐하면 민주주의정부는 순응 적이고 책임성 있는 거버넌스를 제공하는 이외에도 시장의 순기능을 하게 하는 환경조성을 해주기 때문이다. 민주제도하에서 경제개혁은 자동적으로 그리고 동시적으로 소득재분배와 생활수준의 향상 을 가져오는 것은 아닌 것이다. 민주주의 하에 시장개혁은 경제발전의 필수조건이지만 소득불균형을 감소하는데 충분한 것은 아니다. 국가능력, 제도, 책임성, 대표성과 거버넌스의 동시적 개선은 소득 균등을 수반한 경제성장을 달성하는데 중요한 요인들이다.

민주주의도 모든 것을 치유할 수는 없으며 경제적 자유화를 즉각적으로 그리고 쉽게 달성할 수도 없다. 그러나 민주주의는 장기적이고 지속적인 발전을 도모하는데 결정적 역할을 한다. 많은 개도국 은 시장경제와 민주주의가 공존하지 못하는 경우가 많은 것도 사실이다. 이는 많은 제도적 결함 내지 부족에 기인하는 것이다. 시장경제는 개방적인 민주제도 없이는 오래 지탱할 수 없는 면도 있음을 주 목해야 한다.

한편 인도는 민주주의체제하에서 폭력과 희생은 없었지만 매우 느린 경제성장을 경험하였다. 민주 주의의 경제적인 성공의 사례는 2 차 대전 후에 동독과 서독의 경제발전의 차이와 1990 년대 동구공산 권 해체이후 체코와 슬로바키아의 경우가 대표적이다. 1980년대 초에 많은 민주정부(개도국과 이행 경제국의 취약하고 제도화되지 않은 새로운 민주국가를 포함한)들은 막대한 단기적인 희생을 감수하 면서 원대한 시장개혁을 단행하였다. 남미의 칠레와 아르헨티나와 같은 새로운 민주국가들도 이러한 개혁을 성공적으로 단행할 수 있었다는 것이다. 민주주의 사회는 민주주의를 통하여 많은 편익(교육, 보건 및 기타 공공재)을 받게 된다. 민주사회 하에서는 권력을 유지하기 위해서는 정부는 사회적 요 구에 순응해야 한다. 그렇지 않으면 민주정권도 오래 유지 할 수 없게 된다.

\section{2) 권위주의와 경제발전}

de Mesquita와 Downs에 의하면 권위주의적 정부는 경제성장을 촉진시키고 자원을 이용하여 성장 의 과실을 그들에게 돌아가도록 정권을 유지하게 한다. 단기적으로 그러한 목적을 달성하는 경우도 있으나 그들의 지혜와 능력을 과대평가해서는 안 된다. 한편 권위주의적 정부는 시간 소모적인 민주 주의과정을 무시할 수 있으며 고통스러운 개혁을 피할 수 있다. 한편 한국과 대만도 권위주의 시장경

6) UNDP (2006) Governance for the Future: Democracy and Development in the Least Developed Countries, Chapter 1 참조할 것 
제하에서 놀라운 발전을 하였지만 많은 폭력과 희생을 치룬 후 민주화과정을 거쳐 현재는 민주주의 와 시장경제를 공유하게 되었다. 그러나 한국과 대만 및 말레이시아의 성공적 경우는 원칙이라기보 다 예외로 보는 학자가 많다.

1980년대까지 남미와 사하라이남 아프리카의 많은 국가들은 억압적인 권위주의적 정부 하에 지배 를 받았으며 이러한 정부들은 그들이 집권할 때 약속한 원대한 정치적 및 경제적 개혁을 하는데 실패 하였다. 과거 공산치하에 동구의 제국들도 빈약한 실적을 보여주었다. 권위주주의적 제도는 경제발 전의 탁월한 실적을 보여주지 못하였으며 경제적 성공보다 실패의 경우가 훨씬 많았다. 예로는 짐바 브웨의 Mugabe, 자이레의 Mobutu, 필리핀의 Marcos와 투르크메니스탄의 Niyazov 등을 들 수 있다.

한편 중국과 베트남은 사회주의 시장경제하에서 현저한 발전을 보여 주고 있다. 중국의 급격한 경 제발전은 동아시아의 발전모형을 모방하였다고 하지만 사실상 제도적으로 더욱 야심적이다. 특히 중 국의 1990 년대 후기개혁의 성공은 지방정부의 재산권과 행정력의 분권화였다고 본다. 그러나 Pei에 의하면 중국의 발전모형은 지속적 경제성장과 도약을 위해서는 정치의 자유화와 민주화를 필요로 한 다는 것이다. 그러므로 중국은 현 체제 하에서는 성장의 장기적 지속성이 숙제로 남아 있다.

결론적으로 어떠한 정치제도하에서도 거버넌스가 있으며 거버넌스 능력은 각국의 역사, 정치, 경 제 및 사회제도 등에 따라 상이하다. 발전의 결정요인은 국가의 성장정책, 거버넌스 능력 및 기술능 력 등에도 달렸다. 그러나 권위주의정부는 양호한 거버넌스의 모든 원칙을 포용하지 못하며 지속적 인 발전을 유지할 수 없다.

\section{3) 민주주의, 경제발전과 제도 구축}

경제발전을 위하여 필요한 정치적 제도는 민주주주의제도 하에서 존재하며 효과적으로 작용할 가 능성이 있을 뿐만 아니라 적합한 효율성은 민주주의에서 가장 잘 유지/지속된다는 것이다. 왜냐하면 양호한 거버넌스와 경제발전을 증진시키는 제도 구축은 민주주의와 깊은 관계가 있기 때문이다. (Sharma, 2007, p.35) 수세대에 걸쳐서 높은 경제발전을 보여준 국가들은 모두 안정된 민주주의 국 가들이라는 것은 우연이 아니다. 사실상 민주화와 관련된 오랜 연구 중의 하나는 지속적인 민주주의 는 경제발전과 밀접하게 연계되어 있다는 것이다. Adam Przeworski와 공동연구자들은 일국의 1 인 당 GNP가 $\$ 5,500$ 이상에 도달하면 민주주의는 번성하고 유지된다고 주장하고 있다. (Przeworski, et al, 2000)

Lipset 에 의하면 “...... 민주주의는 경제발전의 상태와 연관성이 있다고 한다. 잘 운영하는 국가는 민주주의를 유지할 기회가 더 많다는 것이다”. (Lipset, 1963, p .31) 바꾸어 말하면 거버넌스는 의사 결정을 하고 이를 수행하는 힘이기 때문에 장기적인 지속발전의 중요한 도구이다. 그뿐만 아니라 개 인은 민주제도에 있어서 의사결정과정의 중심에 있으므로 그들의 적극적인 활동은 재화와 서비스의 생산을 극대화함으로서 국가의 경제적 건전성을 크게 강화해 주는 것이다.

Habiso에 의하면 민주주의는 아프리카에서 실패하였다는 것이다. 그 이유는 아프리카의 엘리트 
들이 다음의 사항을 발의하고 기획하고 수행하는데 실패했기 때문이다. (i) 진정한 민주주의, (ii) 공 업화, (iii) 농업개혁, (iv) 농촌개발, (v) 교육, (vi) 기존 사회경제위기에 대한 아프리카적 해결책 등 을 들고 있다. (Habiso, 2011, p.1)

에티오피아는 1930-1974년간에는 중앙집권적이고 봉건적인 권위주의정권이 자유방임적인 경제제 도를 채택하였고 1974-1991간 에는 군사정권이 사회주의경제제도를 채택하였다. 1991년에는 군사정 부가 물러나고 에티오피아 국민혁명민주전선(Ethiopian People's Revolutionary Democratic Front, $\mathrm{EPRDF})$ 이 집권하여 개발 국가 경제제도를 채택하였다. 이는 한국과 대만의 개발전략을 모방하여 소 위 민주적 개발 국가의 제도를 추구한 것이다. 이와 같이 다른 정치 및 경제제도를 바꾸어 가면서 경 제발전을 추구하여 왔지만 결국 모두 실패하고 말았다. 나이지리아도 1999 2009년간에 민주정부 하 에서 공업화정책을 추구하였으나 민주주의는 공업화에 지대한 파급효과를 주지 못했다는 것이다.

수단은 25 년간 경제계획을 수행하였으나 실패하였다고 한다. 이러한 국가들의 모든 실패는 아프 리카 실정에 맞는 거버넌스 제도 구축과 국가능력의 부족에 기인하는 것으로 예견된다. 그러나 보츠 와나, 한국, 대만, 싱가포르, 말레이시아, 중국, 브라질 및 인도는 각기 다른 정치, 경제, 사회 및 문 화제도와 다른 거버넌스 제도를 가지고 있지만 경제발전의 성공 사례 국으로 예시되고 있다. 이는 건 전한 거버넌스 제도와 국가능력을 배양하였기 때문이다. 발전은 내부에서 자체의 힘으로 이루어지며 외부에서는 다만 도움을 줄뿐이다.

경제발전은 장기간에 걸쳐 성장, 보다 좋은 사회서비스와 보다 개선된 평등성을 유도하는 과정을 말하는 것이다. 이러한 발전과정은 자유민주주의 자체만으로 이루어진 것이 아니고 일련의 필요한 제도 구축에 의하여 달성될 수 있는 것이다. 즉, 이러한 제도는 재산권, 사업 환경조성을 위한 정부 의 협조를 통한 투자증진과 정보의 투명성을 통한 책임성의 증대 등을 확보하는 제도를 포함하고 있 다. (Adam Smith, Machiavelli, D. North, D. Rodrik와 P. Keefer)

\section{(2) 민주주의, 개도국의 민주화 과정과 경제발전}

부유국과 빈곤국을 포함한 100 개국 이상의 개도국의 조사에 의하면 경제발전 면에서 민주주의가 권위주의를 압도했다는 것이다. 동아시아의 대만, 한국, 싱가포르와 홍콩을 제외하면 민주주의 국가 의 실적은 더 월등하여 권위주의 국가보다 연 1 인당 0.5 퍼센트 빨리 성장했다는 것이다. 즉, 과거 40 년간에 가장 경제실적이 낮은 80 개국 중 3 개국을 제외한 모든 국가가 권위주주의 내지 독재국가들 이다. 이 연구에 의하면 민주국가간에 개발경험도 성공의 차이가 큰 것이다. 그 이유는 각국의 제도 발전의 차이에 기인하는 것이다. 사실상 민주주의 국가와 권위주의적 국가를 불문하고 건전한 제도 를 가진 국가들은 빈약한 제도를 가진 국가보다 높은 경제발전을 보여주고 있다. 이것이 바로 왜 과 거 동아시아의 권위주의적 국가들이 다른 민주국가보다 더 빠른 발전을 하였는가를 보여주는 이유이 다. (Halperin, et al, 2005) 동아시아의 개발 국가들의 경험은 효율적인 국가능력과 양호한 거버넌스 가 권위주의적인 정부 하에서도 발전할 수 있다는 증거를 보여 주었다. 그러나 이러한 경험은 예외적 
인 것으로 평가되고 있다.

개도국의 미숙한 민주국가와 이행경제국을 포함한 빈약한 민주주의 국가들은 필요한 경제개혁을 수행하기위한 제도적 장치가 부족하여 지탱하기 힘들다. 신자유주의나 시장개혁은 단기적인 고통(실 업, 인플레이션, 국가의 보조금지급상품의 높은 가격, 임금하락 및 기타 규제조치 등)을 감수하면서 수행해야 하기 때문에 정치개혁들은 인기 있는 지지를 받기 힘들다. 그러나 1980년대까지 남미와 사 하라이남 아프리카는 권위주의적 정부 하에서 원대한 정치 및 경제개혁을 수행하는데 실패하였고 동 구의 공산정권도 마찬가지였다. 그러나 동구의 공산체제가 해체된 후에 동구의 가장 민주적인 일부 국가들은 극적인 민주국가로 전환하여 가장 포괄적인 경제개혁을 수행하여 "post-communist paradox" 라고 불리고 있다. 또한 칠레와 아르헨티나에서는 민주정부가 매우 의욕적인 경제자유화를 추진할 수 있었다. 새로운 민주국가들은 이러한 정치적 및 경제적 개혁을 할 수 있다. 왜냐하면 인기 있는 모든 사회의 주체들은 로비, $\mathrm{NGO}$ 의 미디아망, 입법부 대표와 사법부를 통하여 개혁의 압력을 가할 기회를 가지고 있기 때문이다.

민주화 과정이 유지되기 위해서는 (i) 소득이 높거나 급속한 경제성장(Dahl, 2000, p. 191) 그리고 재분배면의 분쟁이 심하지 않아 그들의 해결이 힘으로 보다 법치 하에서 해결되어야 한다. (ii) 고소 득의 중요한 중산층의 형성을 허용할 것, (iii) 보다 높은 교육을 제공해야 한다. 많은 개도국의 민주 화는 상술한 요인과 밀접한 관계가 있다. 이러한 맥락에서 볼 때 경제발전도 민주주화에 일조한다고 볼 수 있다.

역사적으로 보면 경제발전이 선행되고 그다음에 자유민주제도가 도래되었다는 것이다. 현대 선진 국들은 비민주적 또는 고도의 제한된 민주적 여건 하에서 발전되었다. 일부학자들은 1960년대 후반 에 동아시아의 경제적 기적을 낳은 성공사례는 민주주의적 여건 하에서 이루어진 것이 아니라고 논 하고 있다. Adrian Leftwitch에 의하면 보츠와나, 말레이시아와 싱가포르 등의 국가들은 일당제도 (one party rule)하에서 발전하였다고 한다.

Habiso가 말한바와 같이 고통 없이는 사회는 민주주화 될 수 없으며 투쟁 없이는 어떠한 국가도 경제발전을 성취할 수 없다는 것이다. (T. Habiso, 2011). 특히 이행기에는 정책입안자나 주창자들이 단기적인 미봉책(quick-fix solution)을 요구한다면 이는 비현실적이며 그러한 해결책을 시도한다 해도 장기적으로 역효과를 가져오게 된다.

Kofi와 Desa 의하면 아프리카의 개발계획은 (i) 기존 국별 지식과 능력을 바탕으로 수립해야 한다. (ii) 아프리카가 지속적인 발전을 하려면 아프리카인이 개혁의 주도자가 되어야 하며, (iii) 아프리카는 서구의 자본주의 경제이론을 비판적으로 검토해야 한다는 것이다. 왜냐하면 서구국가들은 다른 정 치, 경제 및 사회적 제도하에서 발전해 왔기 때문이다. (Kofi and Desa, 2008, p. 320). 이는 개도국 주도하에 개발계획을 수행해야 한다는 것이다. 이러한 주장은 2005년 파리선언이후 주인의식: 수요 측 거버넌스(ownership: demand-side governance)의 명제 하에 널리 강조되고 있다. 


\section{4. 거버넌스 제도, 민주주의와 지속적 경제발전 간의 관계}

신제도학파(new institutionalism)의 학자들은 중요한 제도(institution)는 장기적으로 경제발전과 민주주의발전에 강력하게 영향을 미친다고 주장하고 있다. 제도란 행동(예컨대 법치와 재산권 등)을 조직하는 규칙체계(system of rules)를 말하며 이들은 시장과 양호한 거버넌스의 기능을 강화시 킨다.

〈그림 3〉은 거버넌스 제도와 민주주의와 경제발전 간의 관계를 나타내는 모형을 제시하고 있다. 이것은 정치 및 경제적 결과의 공동 결정요인으로서 그리고 양자 간의 관계를 연결해주는 주요 연계 자로서 거버넌스 제도를 강조하고 있다. 물론 이 모형은 다른 중요한 변수들(예컨대 중산층의 발전)을 생략하여 단순화한 것이다. 그러나 다음의 두 가지 결론은 매우 유익한 것이다. (i) 성장의 요인(source) 은 민주화와 장기성장에 중요하다. (ii) 정치적 및 경제적 제도는 상호 연결되어 있다. (Bettcher and Shkolnikov, 2009, pp.4-5)

〈그림 3〉에서 보는바와 같이 거버넌스 제도(법치, 공개적인 정책과정, 재산권, 계약법 및 기타 규 정 등)가 경제발전(성장)과 민주주의에 동시에 영향을 미치는 관계를 보여주고 있다. 거버넌스 제도 는 경제발전과 민주주의에 공통적인 요인임을, 그리고 양자 간에 관계를 연결하는 고리임을 부각시 켜주고 있다. 궁극적으로는 한 국가의 경제발전과 민주주의 간에는 상호작용을 하게 된다. 결론적으 로 말하면 거버넌스 제도가 경제발전과 민주주의에 동시에 지대한 영향을 미친다는 것이다.

다음의 세 가지 사항은 매우 중요한 의미를 담고 있다.

1) 거버넌스 제도는 충분하지는 않으나 민주주의에 필요한 것이다. 선거에만 초점을 둔 민주주의 에 대한 온건파(minimalist)는 민주주의가 기능을 하는데 필수적인 법적 체계와 의사결정과정 의 필요성을 간과하고 있다. 자유롭고 공평한 선거는 중요하나 충분하지 못하다. 가령 민주적 결과를 위한 다른 요인들은 시민참여, 사회분열의 구조와 제도의 합법성 등을 열거할 수 있다.

2) 거버넌스 제도는 장기적이고 지속가능한 발전을 위하여 필요한 것이다. 그러나 이러한 제도들 은 단기적인 발전을 달성하는데 필요한 것은 아니다. 제도 이외에도 다른 많은 요인들이 경제 발전에 영향을 미칠 수 있다. 예컨대, 자연(부존)자원, 노동력, 기술접근성, 이용 가능한 시장 규모 등을 들 수 있다. 다시 말하면 경제발전의 질에 관하여 의문을 제기할지 모르지만 경제발 전은 단기적으로 건전한 제도적 기초 없이도 달성할 수 있다.

3) 거버넌스 제도는 유일(무이)한 결과를 만들 수는 없다. 그러나 양호한 거버넌스는 시장경제와 민주주의의 발전을 유도할 수는 있다. 경제발전과 민주주의 간에 관계에 관한 Maxin Pei의 분 석도 이와 유사한 결론을 내리고 있다.(Pei, 1999, pp. 26-27) Pei는 지속적인 경제발전은 다 음과 같은 요인에 의하여 민주주의를 초래한다고 논하고 있다. 즉, (i) 중산층의 육성, (ii) 교육 수준의 제고, (iii) 국가로부터 독립적인 민간부문 활동의 허용, (iv) 시민사회의 강화, (v) 국제 사회와 사회적, 문화적 및 정치적 연계의 증진 등을 열거하고 있다. 또한 그는 민주주의는 주로 
중요한 정치제도를 통하여 경제발전의 가능성을 강화한다고 주장하고 있다.

Pei는 정치적 제도의 논의에서 재산권을 보호하는 수단으로서 법치는 아마도 정치제도와 발전 간의 관계를 논의함에 있어서 핵심적 부분이라고 결론을 짓고 있다. 간단히 말하면 건전한 법 치를 얻을 수 있는 정치체계(political regime)는 지속가능한 경제발전을 달성할 가능성이 농후 하다는 것이다. 법치(rule of law)는 권위주의적 정부보다 민주주의 제도 하에서 얻을 가능성 이 많다. 권위주의적 정부는 자유경쟁(정치적 및 경제적)이 일어날 수 있는 법적 체계를 확립하 기보다는 오히려 권력을 쟁취/유지하는데 법치를 역이용하고 있다.

결론적으로 경제를 지배하는 제도는 역시 민주주의의 질이다. 법치와 재산권은 정부활동을 억제하 고 지대추구(rent-seeking)와 정부지배 대신에 민간의 창의력을 조장 해주며 국가통제에 대한 분쟁 을 감소시킨다. 이러한 제도는 경제활동을 유지하고 규제하는 방향으로 발전되어야 하지만 이들은 정치적 경쟁과 발상의 성격을 규정하게 된다. 그러나 경제발전을 위하여 필요한 정치제도의 형태에 관해서는 명백한 해답이 없는 상태이다. 권위주의적 및 민주주의적 제도는 모두 역사의 다른 기간에 걸쳐 경제발전과 성장을 보여 주었다. 민주주의 국가 간에도 어떠한 민주주의적 장치가 경제발전과 성장에 필요한가에 대해서는 명백한 해답이 없는 실정이다.(Prezworski, 2000)

\section{〈그림 3〉 거버넌스 제도, 민주주의와 경제발전 간의 관계}

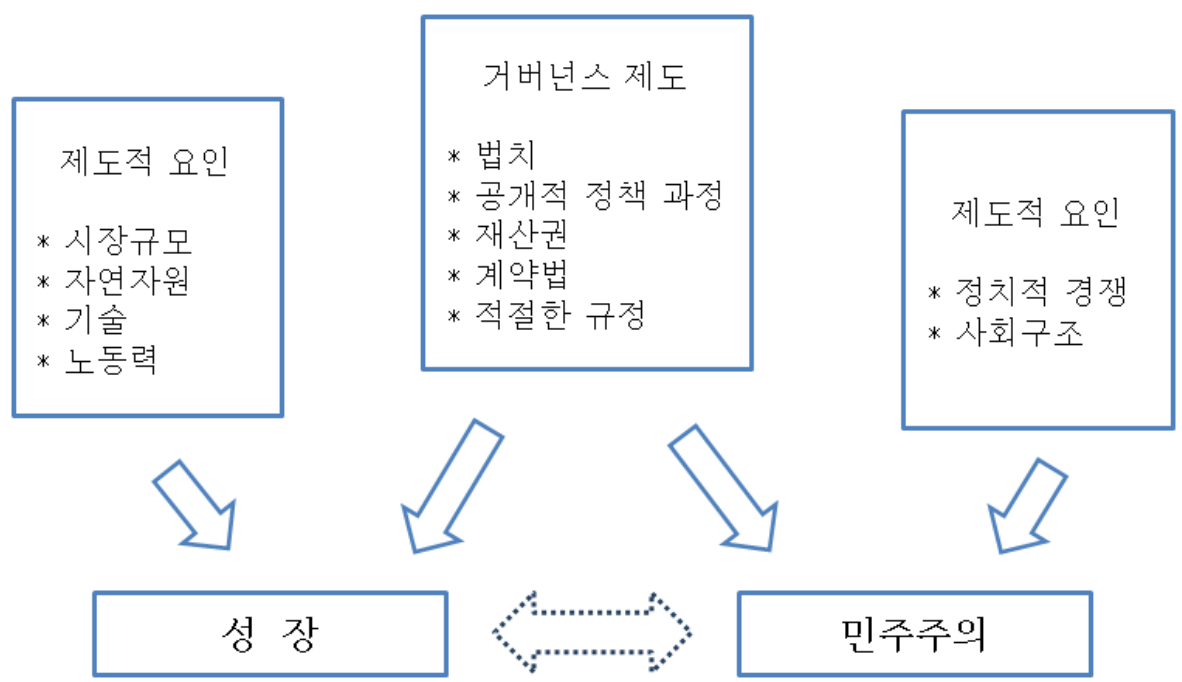

자료 : Kim Erik Bettcher and Aleksandr Shkolnikov, Democratic Govaernance and the Quality of Growth, 2009, p. 5 


\section{5. 발전과정에 있어서 경제, 사회 및 정치적 측면 간의 상호관계}

\section{(1) 경제발전(economic development)}

1) 경제발전의 개념

먼저 경제발전은 국민소득의 증가뿐만 아니라 산업구조, 소득분배 등의 양적 및 질적(구조적) 측 면의 개선을 포함하고 있으며 물질 지향적(material-oriented) 후생에 중점을 두고 있다. 이는 경제 발전의 독자적인 개념규정을 하고 있지만 상당히 제한적 의미를 내포하고 있다. 경제학자들은 최근 까지 정치학의 제 변수들을 외생변수로 보았기 때문에 정책이 경제발전에 미치는 효과만을 관찰하고 정책선택의 결정요인을 분석하지 않았다. 반대로 정치학자, 사회학자 및 역사가들은 외부적인 제약 조건을 국가정책의 결정요인으로 보았다. 결과적으로 경제학자들은 제도와 국내 정치세력을 무시하 였다. (Ahrens 2002, p.2) 그러나 최근에는 그들은 학제 간 연구를 통하여 공동연구를 하고 있다. 신 제도경제학파는 제도의 변화를 인정하고 이러한 학제 간 연구를 강조하며 공동연구의 선구적인 역할 을 하였다. 이러한 접근방법은 현실적인 거버넌스 연구에 매우 유익한 것이다. (North, 1990)

\section{2) World Bank의 발전개념}

발전에 대한 도전은 일반적으로 높은 소득을 요구하며 생활의 질을 개선하는데 있다. 그러나 이 는 그 이상의 것을 포함하고 있다. 그것은 보다 나은 교육, 높은 수준의 보건과 영양, 보다 깨끗한 환 경, 보다 동등한 기회, 보다 많은 개인의 자유와 부유한 문화생활 등을 포함하고 있다. (World Bank 1991, p. 4) 13년 후에 2003년 World Development Report는 경제성장과 높은 소득이 인간개발 수 준(level of human development)에 반영되어야 한다는 논의를 지지하게 되었다. 즉, 지속적인 발전 은 경제성장뿐만이 아니라 환경과 사회문제도 주목해야 한다는 것이다.

경제발전은 기본적으로 기술 및 사회발전과 관련된 일국 경제의 질적 변화와 구조조정을 의미한다. 경제개발의 주요지표는 1 인당 $\mathrm{GNP}$ (또는 1 인당 GDP)의 증감이며 이는 일국 국민의 경제적 생산성의 증가와 평균적인 물질적 후생의 증가를 반영하고 있다. (World Bank 2009a, Chapter 1) 그러나 World Bank은 엄밀한 의미의 경제발전의 개념은 1 인당소득의 증가를 넘어 빈곤의 완화와 보다 개선 된 평등, 교육, 보건 및 영양의 개선과 환경보호 등에도 눈을 돌려야 한다는 것이다. 이와 같이 경제 발전의 개념도 종래의 협의의 물질 지향적 개념에서 광의의 인간중심적 개념으로 발전하게 되었다.

\section{(2) 정치발전(political development)}

정치발전은 매우 복잡하며 최소한 다음의 세 가지 요소를 포함하고 있다. 즉, (i) 국가구축(statebuilding)은 핵심정부제도의 설립 및 강화(안보기구, 사법제도, 경제제도, 사회복지제도, 보건 및 교 육 등)와 자립적인 정치 및 경제제도 확립 등을 포함하며 이는 보통 국가능력(state capacity)의 기초 
를 이룬다. 효과적인 국가능력은 거버넌스 제도가 실적위주로 조직되고 규정에 따라 운영되는 것을 의미한다. (ii) 법치는 명백하고 투명한 공식적인 규정에 따라 업무를 수행하며 재산권과 개인의 인권 을 보호한다. (iii) 민주주의는 정기적인 다당제 선거를 통한 인기 있는 주권의 행사이다. 언론, 집회 및 결사의 자유 등을 포함한다. (World Bank, 2008, pp.25-29)

\section{(3) 사회발전(social development)}

사회발전은 발전의 목표가 인간생활의 질적 향상을 도모하는데 있으므로 단순한 소득증가 이외에 보다 나은 교육, 높은 수준의 보건과 영양, 기회균등 및 보다 높은 문화생활을 말한다. 또한 복잡한 분업의 출현과 사회적 신분의 변화(중산층 출현)등 사회변동을 포함한다. 여기에서는 사회발전을 경 제발전과 정치발전의 중간 변수로 보고 있다.

\section{(4) 지속적인 인간개발(sustainable human development, SHD)}

지속가능한 인간개발은 미래세대의 기회를 손상하지 않고 현재의 인간욕구를 충족하는 과정을 의 미한다.(UNDP, 1997) 다시 말하면 지속적인 인간개발은 경제적으로 실행 가능할(viable) 뿐만 아니 라 사회적으로 정당(just)하고 환경적으로 지속적(sustainable)이어야 한다. 인간 지향적(humanoriented)후생에 중점을 두고 있다. 결론적으로 경제발전은 물질지향적인 반면 지속적인 인간개발은 인간지향적인 점에서 매우 대조적이다. 구체적으로 말하면 $\mathrm{SHD}$ 는 물질적, 정신적 및 사회적 후생을 더욱 증대시킬 목적으로 모든 사회구성원의 practical needs(보건, 식량, 수도, 위생, 주택, 의류 등) 와 strategic interest(평등권, 교육, 위해한 전통적 관습의 제거, 재생산적 자유, 여성에 대한 폭력 의 제거 등)를 개선하는 과정이다. 지속적인 인간개발은 경제, 정치, 사회 및 환경 등 네 가지 측면을 내포하고 있는 보다 종합적인 개념이다. SHD는 현실적으로 사용가능한 총체적 발전개념에 속하는 것이라고 볼 수 있다. 이것이 우리들의 발전의 목표가 되어야 할 것이다.

\section{(5) 경제, 사회 및 정치발전 간에 인과관계와 연쇄효과}

여기에서는 경제발전 1 개, 정치발전 3 개 와 사회발전 1 개를 발전의 5 개 목표로 가정한다. 〈그림 4 는 경제, 사회 및 정치의 5 개 목표 간에 상호관계를 표시한 것이다.

1) 정치측면에는 국가구축, 법치와 민주주의가 있는데 이들은 경제발전에 각기 다른 영향을 미친 다. 예컨대, (i) 국가능력은 1 인당 GDP가 1000 달러 이하일 때에는 법치나 민주주의보다 더 중 요하다. 1960 년대와 1970 년대 한국과 1978 년 개방이후 중국은 강력한 법치제도를 가지지 못하 였다. 따라서 법의 하부구조도 매우 취약하였다. 이 두 국가는 개발 국가로서 정치질서와 친개 발 국가 정책을 추구하였다. (ii) 민주주의와 경제성장간에 관계는 매우 복잡하다. 즉, 민주주의 가 경제발전에 미치는 효과가 경제발전이 민주주의에 미치는 효과보다 크다는 것이다. (Lipset, 
1959 ) (iii) 재산권은 개인의 인권(언론, 집회 및 종교의 자유)보다 성장에 더 중요한 국가들도 있다. 예컨대 중국, 말레이시아, 싱가포르, 아랍 에미리트연합 등을 들 수 있다.

〈그림 4〉경제적, 정치적 및 사회적 측면의 상호작용

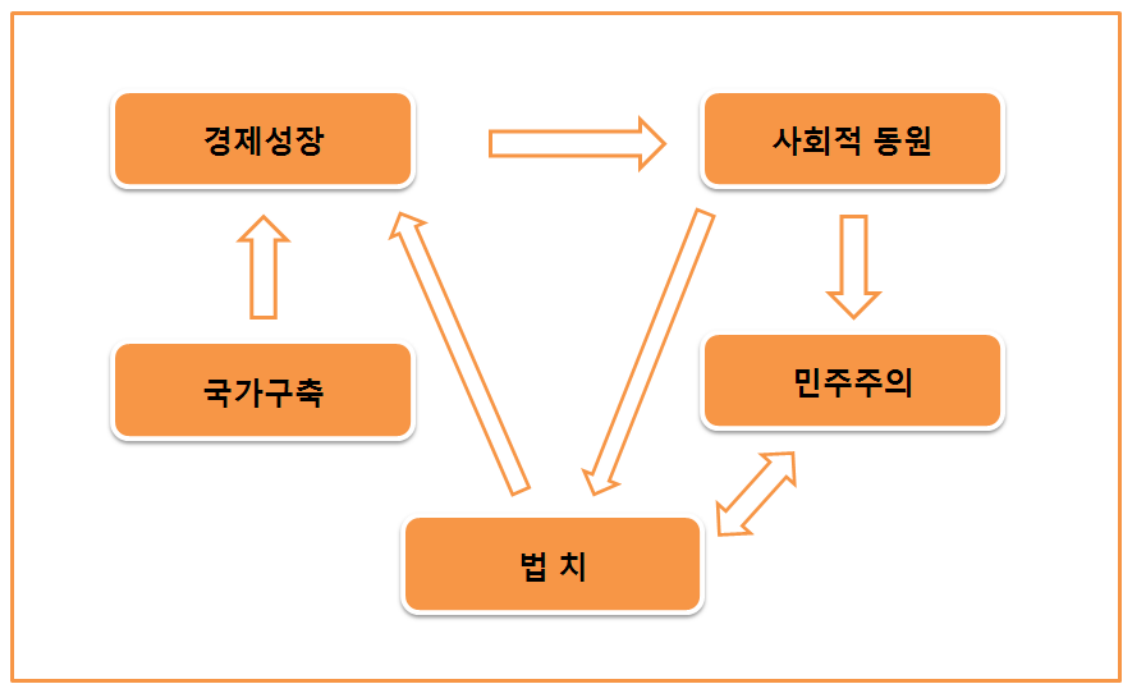

자료 : World Bank,Governance, Growth and Development Decision-making, 2008, p. 26

2) 경제적 측면을 볼 때 경제발전은 사회적 결과와 정치적 결과에 영향을 미치며 궁극적으로는 제 도변화와 경제성장에 영향을 미친다고 한다. 경제성장이 지속되고 기업이 규모의 경제를 이용 하게 되면 사회적 전문화는 증대하여 새로운 사회계층(산업노동 계급)이 출현하게 된다. (World Bank, 2008, p. 30)

3) 사회적 측면을 보면, 경제발전의 결과 새로운 사회계층의 출현은 국가구축, 법치 및 민주주의에 영향을 미치며 종국적으로 경제성장에 영향을 미친다. 한편 경제발전은 중산층을 배출하여 이 들은 그들의 재산을 보호하는 법치를 요구하게 되고 드디어 정치참여를 하게 된다. 경제성장과 안정된 자유민주주의간에 관계는 이러한 경로를 통하여 조정되게 된다. 다시 말하면 경제성장 은 새로운 사회주체(주역)들을 출현시키며 그들은 공개적인 정치제도의 대표를 요구하게 된다. 만약 정치제도가 이러한 계층을 수용하게 되면 한국과 같이 정치안정과 장기적 경제성장을 달 성하게 될 것이다. (World Bank, 2008, pp.30-31)

\section{(6) 개발전략과 우선순위}

F. Fukuyama에 의하면 발전에 있어서 적어도 5 개의 경제적, 정치적 및 사회적 측면이 있는바 개 발전략을 위해서는 그중 어느 하나도 출발점(entry point)이 될 수 있다고 본다. (i) 일부 학자들은 민주주의와 사회동원대신에 경제발전, 국가구축 및 법치 등에 우선순위(출발점)를 두어야한다고 주 
장한다. Huntington과 Zakaria는 민주주의와 경제성장간의 관계보다 국가능력, 법치 및 경제성장간 의 관계가 더 강력한 관계(예, 한국과 대만)를 지니고 있다는 것이다. (iii) 경제성장과 국가구축(국가 능력)을 출발점으로 할 수 없는 국가들은 다른 출발점을 선택해야 할 것이다. 가령 브라질, 콜롬비아 와 페루와 같은 중소득 국가들은 민주주의의 질을 향상시키는 출발점을 택하여 법치의 강화와 경제 발전을 촉진시킬 수 있는 것이다. (iv) Huntington에 의하면 우크라이나는 경제적 침체, 심각한 부 패 및 투명성의 부족 등 무책임한 정치제도를 가지고 있는데 이러한 국가는 발전을 위해서는 사회적 동원(예, 오렌지 혁명)이 출발점이 되어야 한다고 주장하고 있다. (v) World Bank와 다른 국제기구 들은 좋은 제도는 경제성장을 일으키기 때문에 제도개혁이 경제발전의 출발점이 되어야 한다고 주장 하고 있다. (World Bank, 2008, pp. 31-33) 이는 매우 중요하고 효과적인 출발점인 것이다. 결론적 으로 말하면 발전전략의 입안자들에게는 많은 선택의 여지가 있으므로 전략의 선택은 각 개도국의 역사적 사정에 따라 결정해야 할 것이다. 따라서 그들의 출발점은 각국에 따라 상이하며 우선순위의 결정도 각 개도국의 특수한 사정에 따라 해야 될 것이다. 이러한 순환론적 입장에서 개도국이 중요한 측면을 선정하여 출발점으로 삼아야 할 것이다.

\section{IV. 민주적 거버넌스 지표의 분석}

\section{1. 거버넌스 지표}

거버넌스 지표의 측정 목적은 이 지표들의 정밀분석을 통하여 종합적인 거버넌스의 평가를 하기 위한 것이다. 다시 말하면 (i) 각 개도국의 거버넌스의 상황파악, (ii) 빈약한 거버넌스의 원인 발굴. (iii) 거버넌스 개혁의 우선순위 및 변화의 모니터링, (iv) 가장 적절한 원조정책의 수립 등을 하기 위 한 것이다. 이러한 거버넌스의 종합적 평가는 개발협력기구들에게 원조금액, 일정표의 작성, 활동범 위와 원조의 형태 등을 결정하는데도 도움을 준다. 요컨대 이러한 자료의 분석을 통하여 세계의 개도 국의 거버넌스가 어떻게 변화하며 주요한 거버넌스 개혁의 과제가 무엇이며 적절한 원조정책이 무엇 인가를 발견하는데 있다.

거버넌스 지표들은 수없이 많지만 그중 중요한 몇 개를 들면 (i) Fund for Peace의 Political Indicators(Fund for Peace 2010), (ii) Freedom House의 Freedom Index(Freedom House 2010), (iii) Transparency International의 Corruption Perception Index(Transparency International 2010), (iv) Nation Master의 Public Institution Index(Nation Master 2010), (iv) Worldwide Governance Indicators(WGI) 20097) 등을 열거할 수 있다. 여기에서는 많은 지표 중에서 World

7) 그 이외 많은 거버넌스 지표가 있는바 상세한 지표는 김달현, "거버넌스와 개발", 국제개발협력의 이슈, 한국국제협력 단, 2011. pp. 133-139 참조 
Bank의 World-wide Governance Indicators(WGI)만을 중심으로 논의하려고 한다.

World Bank의 “세계 거버넌스지표 프로젝트”(World-wide Governance Indicators Project)는 현 재 1996-2009 간에 걸쳐 212개국에 대하여 6개 거버넌스 지표로 나누어 발표하고 있다. 거버넌스의 지표는 아래와 같이 6 개의 지표와 그 평균으로 분류하며 각 항의 정의는 다음과 같다. (World Bank 2009b, pp.1-2) 즉, (i) 시민참여(voice and accountability): 일국의 시민이 그들의 정부를 선택하 고 언론, 출판 및 집회에 참여할 수 있는 민주주의의 실현 정도를 말한다. (ii) 정치안정(political stability): 정부가 비헌법적 혹은 폭력적 수단(테러를 포함)에 의하여 불안정하게 되는 가능성을 의 미한다. (iii) 정부효율성(government effectiveness): 공공서비스의 질, 행정사무의 능력과 정치적 압력으로부터의 독립 및 정책수립의 질 등을 포함하고 있다. (iv) 제도 구축(regulatory quality): 민 간부문을 진흥시킬 수 있는 건전한 정책과 규정을 제공하는 정부의 능력을 의미한다. (v) 법치(rule of law): 모든 기관이 사회의 규정(재산권의 질, 경찰, 법원, 및 범죄의 위험 등을 포함)에 따라야 하 는 신뢰의 정도를 말한다. (vi) 부패방지(control of corruption): 공적 권력이 개인적인 이익(작고 큰 형태의 부패와 국가의 엘리트층의 포섭 등)을 위하여 행사되는 정도를 말한다.

국별 거버넌스 지표를 비교하기 위하여 아시아에서는 한국, 중국, 인도, 싱가포르 및 우즈베키스 탄을, 아프리카에서는 보츠와나, 짐바브웨, 에리트레아, 코티브아르를, 중남미에서는 브라질, 칠레, 베네수엘라, 콜롬비아 및 가이아나를, 동유럽에서는 체코와 벨라루스를 각각 선정하였다. (World Bank 2011k). 그러나 상술한 국가들을 성공국가사례와 실패 내지 취약국가의 사례 등으로 나누어 논하려 고 한다.

\section{2. 성공국가의 사례}

\section{(1) 체코}

체코는 1990년대 동구공산권 해체 후에 시장경제를 도입한 이행경제국이다. 동구가 사회주의 경 제체제를 유지하는 동안에도 체코는 가장 발전된 국가였으나 동구해체 후에 체코슬로바키아는 체코 와 슬로바키아로 분리/독립하였다. 체코는 2009 년 현재 1 인당 GNI가 17,310 달러이다. 이 나라는 지 리적으로나 문화적으로 서구와 인접하여 상당히 발전된 국가이다. 체코는 막대한 고통을 참고 시장 경제를 위한 구조적 및 제도적 개혁을 단행하여 성공적인 시장경제체제로 이행하게 되었다. 지금은 동구 제국 중 가장 급속히 성장하고 안정된 국가이다. 그러나 1990 년 초부터 경제개혁을 단행하는 동안 많은 고통(즉, 실업, 인플레이션 등)을 이겨 냈다. 오늘날에는 세계은행으로부터 졸업을 한 상 태이다. 2009년 현재 거버넌스 지표를 보건대, 체코는 거의 한국보다 높은 거버넌스의 수준을 유지 하고 있다. 시민참여(82.9), 정치안정(81.1), 제도구축(86.2)와 법치(81.1)등으로 다른 개도국에 비하 면 매우 높은 편이다. (World Bank, Czech: Country Brief 2010) (〈표 1〉참조) 


\section{(2) 한국}

한국은 1962 년부터 제 1 차 5 개년계획을 시작으로 한국을 빈곤의 악순환으로부터 해방한다는 모토 하에서 정부가 개발계획을 강력 시행하여 1997 년 제 7 차 5 개년계획을 성공적으로 완료하였다. 정치지 도자의 경제발전에 대한 강력한 의지와 발전의 이익을 모든 국민이 공유(shared policy)케 함으로써 국민이 경제활동에 적극적으로 참여하게 만든 것이 성공의 열쇠이다. 한국은 1960 년대 초부터 1970 년대 말까지는 국가가 적극적으로 개입한 성장촉진적인 거버넌스 정책을 채택하였지만 기본적으로 시장경제로 가는 길을 도운 것이다. 그리하여 1980 년대 초부터는 한국경제가 시장경제의 기반을 확 립함에 따라 민간 기업이 중심이 되는 시장촉진적인 거버넌스로 이행한 것이다. (김달현, 2010, pp.147-149)

〈표 1〉성공 사례국의 거버넌스 지표의 비교, 2009

\begin{tabular}{c|c|c|c|r|r|r|r|r}
\hline 구분 & 체코 & 한국 & 보츠와나 & 중국 & 인도 & 싱가포르 & 칠레 & 브라질 \\
\hline 시민참여 & 82.9 & 68.2 & 58.5 & 5.2 & 60.2 & 34.1 & 74.9 & 62.1 \\
\hline 정치안정 & 81.1 & 52.4 & 79.7 & 29.7 & 13.2 & 90.1 & 69.3 & 54.2 \\
\hline 정부효율 & 79.0 & 83.3 & 70.0 & 58.1 & 54.3 & 100.0 & 85.7 & 57.6 \\
\hline 제도구축 & 86.2 & 75.2 & 69.0 & 46.2 & 44.3 & 100.0 & 93.8 & 55.2 \\
\hline 법 치 & 81.1 & 82.5 & 67.0 & 45.3 & 55.7 & 92.5 & 87.7 & 49.5 \\
\hline 부패방지 & 69.5 & 71.4 & 75.7 & 36.2 & 46.7 & 99.0 & 89.5 & 56.2 \\
\hline
\end{tabular}

자료 : World Bank

2009년 현재 한국은 정부의 효율성, 제도 구축 및 법치 면에서 장족의 발전을 하였다. 특히 효과 적인 관료제도와 유능한 공무원들은 창의적인 정책입안과 효과적인 정책수행을 한 것이 주목할 점이다. 그러나 아직도 발전의 여지가 많지만 다른 개도국에 비하면 매우 양호한 편이다. 한국은 과거 50 년 간에 비약적인 정치, 경제 및 사회적 발전을 이룩하였지만 선진제국에 비하면 아직도 시민참여(68.2), 정치안정(52.4), 제도구축(75.2) 및 부패방지(71.4) 면에서 개선의 여지가 아직 많다.(〈표 1〉참조)

\section{(3) 보츠와나}

아프리카의 보츠와나는 1966년 독립 후 40여 년간에 장족의 발전은 아시아 신흥제국을 압도할 정 도이다. 보츠와나의 지도자는 국가의 미래를 발전시키는 성공적인 전략을 채택하였고 다인종적인 민 주주의사회를 확립하였다. 이 나라는 성숙화 되는 민주주의를 자랑으로 여기고 있다. 자유롭고 공평 한 선거가 정규적으로 진행되고 헌법은 기본권과 자유를 보장하고 있다. 정치사회는 현저히 안정되 어 있다. 독립 후 10 년 안에 이 나라는 다이아몬드를 수출하여 그 수입으로 생산 활동, 사회 인프라 구축과 보건 및 교육에 투자하였다. 따라서 다이아몬드 산업은 경제성장의 원천이 되었고 이러한 국 
가주도의 개발전략은 급속한 발전을 촉진시켰다. 이 나라의 거시경제 및 재정적 관리와 더불어 양호 한 거버넌스와 경제성장은 특기할만하다. 따라서 지난 40 여 년간의 발전은 국민의 $2 / 3$ 정도의 생활수 준을 향상시켰다.

2009년 현재 거버넌스 지표를 보면, 정치적 안정(79.7), 정부효율(70.0), 제도 구축(69.0)과 부패 방지(75.7)는 상당한 발전을 이루고 있다. 반면에 시민참여와 법치는 약간 퇴보한 상태이지만 개도국 중 높은 수준을 유지하고 있다. (〈표 1〉 참조)

\section{(4) 중국}

중국은 1978년 개혁개방정책을 채택한 후에 놀라운 경제발전을 가져왔으며 수백만 명을 절대빈곤 에서 탈피하게 하였다. 공산당하에 사회주의 시장경제를 운영하는 중국은 농촌 및 도시경제의 활력 소를 불어 넣었고 인간개발 지표면(문맹률, 보건지표 및 유아 사망률 등)에서 상당한 개선을 보여 주 었다. 중국은 한국, 대만 및 싱가포르와 같이 권위주의적 정부 하에서 개발국가로서의 개발전략을 채 택하였다. 이와 같이 중국이 현저한 발전을 가져온 것은 이미 존재하고 있는 거버넌스 능력이 있었기 때문이라고 보고 있다. 특히 중국은 거대한 국가이지만 이를 지방 분권화(행정과 재산권)하여 상당한 부분 경제운영의 의사결정을 지방정부에 이양한 것이 성공적 요인의 하나로 보고 있다. 이러한 분권 화는 거버넌스의 능력이 뒷받침해야 성공할 수 있다.

1990년대 이후 빈곤은 많이 감소되었지만 서부와 먼 내륙지방의 자원이 부족한 204백만 이상의 국민이 아직도 빈곤상태에 있으며 도시의 빈곤층도 증가하고 있다. 더욱이 중국은 도전과제로 소득 불평등, 공기업의 민영화, 부패, 서부와 동북부의 경제적으로 낙후된 지역, 지탱할 수 없는 자원의 획득과 지역 및 세계적 경제통합과 관련된 문제 등이 당면한 많은 도전과제를 안고 있다. 중국은 과 거 30여 년간에 성공적인 경제성장에도 불구하고 폐쇄적인 정치제도로 많은 경제적 불균형을 자아냈 으며 이는 미래의 발전을 잠식할 것이며 인도와 같은 가장 민주주의국가와 비교할 때 장기적으로 보 다 낮은 경제실적을 보여줄 가능성이 농후하다.

2009년 현재 거버넌스 지표를 보면, 정부의 효율성(58.1), 제도 구축(46.2), 법치(45.3)및 부패방 지(36.2) 면에서 다른 개도국에 비하면 높은 수준이지만 정부효율성을 제외하고는 퇴보현상을 보여 주고 있다. 반면 시민참여(5.2)와 정치안정(29.7) 면에서는 오히려 낮은 수준인 동시에 퇴보현상을 보여주고 있다. 특히 민주주의의 척도인 시민참여는 가장 낮은 수준을 보여주고 있다.

\section{(5) 인도}

오랫동안 잠자던 인도는 오랜 잠에서 깨어나 지난 20 년간 규모나 속도 면에서 역사적으로 전례가 없는 지속적 발전을 해 오고 있다. 인도는 1947년 독립 당시에는 많은 빈곤층을 보유하였지만 현재 는 막대한 절대빈곤층의 반 이상을 구제하였다. 인도는 과거 62 년간에 걸쳐 여러 측면에서 성공적인 
업적을 남겼다. 인도는 (i) 의회민주주의를 유지하면서 발전, (ii) 절대빈곤층의 감소, (iii) 문맹율의 급격한 감소, (iv) 보건사정의 개선, (v) 과거 수년간 가장 세계에서 빨리 성장하는 경제, (vi) IT, 사 업과정 outsourcing, 통신 및 약품의 선두주자로 등장 등을 열거 할 수 있다. 그러나 인도의 도전과 제는 중소기업의 육성, 농촌개발과 고용, 서비스부문의 개발, 사회간접자본의 구축과 도시개발 등을 들 수 있다.

2009년 현재 인도의 거버넌스 지표를 보면 시민참여(60.2), 정부효율(54.3), 제도 구축(44.3), 법치 (55.7) 및 부패방지(46.7) 면에서 커다란 개선이 이루어진 반면 정치안정(13.2) 면에서는 퇴보현상을 보여주고 있다. 그러나 시민참여, 법치 및 부패방지면에서는 중국보다 높은 수준을 보여주고 있다.

\section{(6) 싱가포르}

싱가포르는 도시국가로서 Lee Kuan Yew 전수상이 발전의 계기를 만들었다. 그는 "경제발전이 우 선이고 민주주의는 차후에”라는 것을 하나의 신조로 삼았다. 그는 주장하기를 이것은 권위와 가정의 존경에 관한 유교적 전통이며 개인적 권리에 앞서 공동체에 우선권을 둔다는 것이다. 이러한 사상은 서구적 자유주의에 반하는 이론인 것이다. 이러한 아시아적 가치는 바로 동아시아의 발전 패턴에 기 여 했다는 것이다. (Dalton and Ong, 2005, p.1). 그에 의하면 단기적인 시민 또는 정치 권리는 원칙 적으로 공동체에 보다 큰 선(good)의 이익을 위하여 희생될 수 있다고 본다. Lee Kuan Yew 전수상 은 싱가포르, 한국과 중국이 인도, 자마이카와 코스타리카 등 보다 덜 권위주의적인 국가보다 빠른 경제성장률을 보여주었다는 것을 경험적으로 보여 주고 있다. (Sen, 1999a, p. 10)

중계무역을 통하여 원자재를 구입/가공(봉합지제작과 석유정유 등)하여 재수출하는 것부터 시작하 였다. 싱가포르는 이러한 경제활동을 하기에는 다른 국가에 비하여 경쟁력이 있는 전략적 항구이다. 싱가포르의 항구인프라와 숙련노동력은 수출입시장접근에 절대적으로 우월성을 지니고 있다. 싱가포 르는 국내시장이 작고 자연자원이 부족하여 정부는 친 기업, 친 외국투자 및 수출 지향적 경제정책 을 채택하였다. 이와 더불어 정부는 전략적 정부소유 공기업부문에 국가주도의 투자를 하였다. 싱가 포르정부는 경제를 지도하고 의료부부문과 인프라에 투자하는 방향을 취하였다.

싱가포르는 부패 없는 정부, 숙련노동력과 선진화되고 효율적인 인프라를 가지고 있어 3000 개 이 상의 다국적기업을 미국, 일본과 유럽으로부터 유치하였다. 외국기업은 경제의 거의 모든 분야에 걸 쳐 활동하고 있었다. 이러한 다국적기업은 제조업생산품과 직수출판매(the sale of direct exports) 의 $2 / 3$ 이상을 차지하고 있었다. 1960 년대부터는 각 시대에 알 맞는 정책을 채택해 왔다. 즉, (i) 1960 년대에는 숙련되고 훈련된 노동력의 활용, (ii) 1970년대에는 저임금산업 육성(노동숙련과 기술의 활용), (iii) 1979년에는 자본집약적이고 기술집약적인 산업육성, (iv) 1980년대에는 컴퓨터 및 관련 제 품, 전자의료기구, 자동차부품, 화학제품, 의약품, 안경 및 복사기 등에 집중 투자하였다. 1985-86 년간에는 정부는 새로운 시장개척과 다국적기업을 위한 제조업, 금융 및 통신센터를 세웠다. (v) 최 근에는 생산주도형 경제로부터 혁신주도형 경제로 전환하고 있다. 
2009년 현재 싱가포르의 거버넌스 지표를 보면 시민참여를 제외하고는 정치안정(90.1), 정부효율 성(100), 제도 구축(100), 법치(92.5) 및 부패방지(99.0)에서 선진국보다도 우월하다. 시민참여(34.1) 는 민주주의 척도로 매우 낮은 편이다.

엄격한 법치제도와 부패 없는 사회에서 (i) 정부는 훌륭한 정책을 입안하고 이를 효과적으로 수행 하고 있다. 그리고 시장경제를 활성화시키는 친사업 환경조성정책을 수행하고 있다. (ii) 민간부문은 친사업 환경 하에서 효율적인 경제활동을 통하여 시장경제와 경제발전에 크게 기여하고 있다. (iii) 시민사회는 제한적이나마 정부와 민간부문사이에서 주로 비정치적인 문제의 조정자 역할을 착실하게 담당하고 있다.

싱가포르의 발전은 건실한 거버넌스 하에서 시대의 변화에 따라서 정부는 알맞는 정책을 채택하여 성공적으로 수행하여 왔다. 이러한 발전과정은 모든 개도국에 많은 교훈을 주고 있다. 법치와 부패방 지에 관한 한 싱가포르는 타의 추종을 불허 한다.

\section{(7) 칠레}

이 나라는 August Pinochet 장군이 1973년 쿠데타로 집권하여 17년간 통치하였다. 그러나 민주 화 이후 이 나라는 남미에서 가장 안정되고 번영한 민주국가중 하나이다. 1990년 민주주의로 복귀 후에 이 나라는 경제개혁, 진취적인 사회투자, 투명한 공공행정과 안전하고 여론을 통한 합의를 바탕 으로 한 정부를 운영하여 왔다. 칠레는 남미에서 가장 빨리 성장하는 경제중의 하나이다. 1990년 민 주주의로 복귀한 후에 15 년 동안에 높은 성장률을 보여주어 1 인당 실질 국민 소득이 배가하여 2009 년 현재 1 인당 국민소득은 9,470 달러이다. 2009년 말에는 칠레는 $\mathrm{OECD}$ 에 가입한 남미의 최초국가 가 되었다. 그러나 칠레의 도전과제는 경제성장의 둔화로 인한 생산성의 향상과 소득의 불평등이다. (World Bank, Chile: Country Brief, 2010)

2009년의 거버넌스 지표를 보면 칠레는 6개 지표 모두가 한국보다 높은 편이다. 시민참여(74.9), 정치 안정(69.3), 정부효율(85.7), 부패방지(89.5)는 1996년 이래 향상되었고 법치(87.7)가 약간 퇴 보하였지만 높은 편이다. 반면에 정치 안정(69.3)은 가장 낮지만 1996년 이래 일정한 수준을 유지하 고 있다. 남미에서는 성공적 사례로 보인다. 칠레와 한국의 경우 경제성장이 권위주의적인 정부 하에 서 시작되었지만 이러한 지속적 성장을 지탱하게 한 것은 보다 공개적인 민주주의체제로 이행했기 때문이다.

\section{(8) 브라질}

이 나라는 세계에서 8위의 부유한 국가로 2010년 현재 GDP가 2.1조 달러 이다. 1인당 GNI는 2009년 현재 7,770 달러이다. 남미에서는 이 나라는 면적과 인구 면에서 가장 큰 나라이다. 이 나라 는 경제적 호항과 불황을 경험한 국가로 이들의 발전은 인플레와 과도한 외채로 인하여 둔화된바 있 
지만 1990 년대의 개혁과 현재 진행하고 있는 건전한 거시경제 및 사회정책은 안정, 성장 및 사회적 이익을 계속 누리게 하였다. 브라질은 무한한 자연자원과 강력한 공업발전의 잠재력을 가지고 있지 만 아직 부유국과 빈국 간에 커다란 격차를 줄이지 못하고 있다. 최근의 혁신적인 사회프로그램과 보 다 포괄적인 성장은 이러한 불평등을 점차 감소시켜 오고 있다. 미시 경제적 및 제도적 개혁의 상당 한 진척에도 불구하고 비 인플레적인 잠재적 성장은 많은 장해 및 규제와 동시에 부적절한 인프라와 빈약한 사업 환경에 의하여 아직도 제한을 받고 있다. 정부지출에 비하여 정부서비스의 질은 다른 중 소득(middle income)국가에 비하여 매우 낮은 편이다. 이 나라의 도전과제로는 인프라의 조성, 극심 한 지역 격차(특히 사회지표)와 빈부격차 등을 들 수 있다.

2009년 현재 거버너스 지표를 보면 브라질은 전반적으로 칠레보다는 매우 낮은 수준이다. 그러나 시민참여(62.1), 정치안정(54.2), 정부효율(57.6), 제도구축(55.2) 및 부패방지(56.2)는 1996년 이래 향상되고 있으며 매우 높은 수준을 보여 주고 있다. 법치(49.5)는 1996년 이래 변동이 없으며 정치안 정(54.2)은 가장 낮지만 1996년 이래 일정한 수준에 머물러 있다. 같은 연방 제도를 택하고 있는 인 도와 비교하면 법치를 제외하고는 모든 지표가 인도보다 높은 편이다. 특히 정치적 안정은 인도보다 월등히 높은 편이다. 이러한 차이는 정치제도와 그 운영, 인종 및 종교와 언어, 기득권단체, 정치적 압력단체, 사회신분제도 등 다양한 요인에 기인할 것으로 예견된다.

\section{3. 실패국가의 사례}

\section{(1) 짐바브웨}

아프리카 대륙에 있는 짐바브웨는 1980년 독립이후 29년간 Mugabe가 집권하고 있다. 1인당 국민 소득은 2008년 현재 148달러이다. 1일 1 달러 미만 소득층은 56.1 퍼센트이다. 2008년 대선이후 선 거부정으로 야당과 분쟁관계에 있었는데 2009년에 여야 권력 공유 정치협상 결과 2년간 연립정부구 성에 합의하였다. 현재 Mugabe는 대통령으로, 야당인 Tsvangiri는 총리로 취임하였다. 이러한 정 치 분쟁으로 경제는 파탄에 빠졌다. 그의 독재정부는 자기 자신의 부를 증대시킨 반면에 국가적 성장 을 희생시켰다. 현재 이 나라가 당면한 문제는 경제침체, 거버넌스와 부패방지, 농업문제, 인프라, 기본 서비스와 사회 보호 등이다. 이 나라는 가장 낮은 수준의 거버넌스 지표를 보여 줄 뿐만 아니라 1996년에 비하여 2009년에는 전 지표에 걸쳐서 매우 심각한 악화추세를 보여주고 있다. 가장 우수한 지표의 실적을 100 으로 할 때 모든 지표의 실적이 10 미만으로 가장 실패한 국가의 표본인 것이다. 즉, 법치(0.9), 제도 구축(1.4), 부패방지(1.9), 정부효율(2.4) 와 시민참여(6.6)이다. 또한 동기간에 정치, 경제, 사회 등 제 분야에 걸쳐서 발전이 퇴보되고 있음을 알 수 있다. 거버넌스의 기반이 전혀 구축되지 않은 국가이다. 짐바브웨는 취약국가(fragile states)중 표본국가로 간주되고 있다. 민주국 가의 대열에 합류하기에는 요원한 감이 있다.(〈표 2〉참조) 


\section{(2) 코티브아르}

서아프리카에서 나이지리아 다음으로 큰 국가이다. 경제적인 잠재력을 가지고 있지만 수년간에 걸 친 정치적 및 군사적인 위기는 2002년 국가를 무력 분쟁에 의하여 양분시켰으며 빈약한 거버넌스가 이 나라의 무거운 짐으로 되어 한때 아프리카의 모델국가였던 국가가 오랜 내란으로 인하여 취약국 가(fragile state)로 전락하게 되었다. 아프리카의 5 개국 정상은 와타라를 정당한 대통령으로 재확인 하고 국가화합을 위하여 야당인사를 포함한 통합정부구성을 제안하였다. 현재 당면한 과제는 (i) 법 및 치안질서 확립, (ii) 식량, 구호품, 의약품의 인도적 지원, (iii) 국가화해, (iv) 경제재건 등이다. 또한 제도적 능력의 격차가 현저하여 민간 및 교육부문, 시민사회, 국회의원 및 메디아의 참여를 위 한 제도개혁이 과제로 등장하고 있다. 분쟁을 겪은 취약한 국가로서 많은 과제를 안고 있다. 2009년 에 현재 모든 거버넌스 지표가 악화되고 있으며 시민참여(14.2)와 제도 구축(19.5)을 제외하고는 모 든 지표가 10미만이다. 즉, 법치(6.1), 부패방지(9.0) 과 정부효율(9.5)등으로서 짐바브웨와 동열에 속하고 있는 실패사례의 국가이다.

〈표 2〉실패 사례국의 거버넌스 지표의 비교, 2009

\begin{tabular}{c|c|c|c|c|c|c|c|c}
\hline 구분 & 코티브아르 & 에리트레아 & 벨라루스 & 베네수엘라 & 가이아나 & 콜롬비아 & 우즈베크 & 짐바브웨 \\
\hline 시민참여 & 14.2 & 0.9 & 7.1 & 26.1 & 51.7 & 42.7 & 2.4 & 6.6 \\
\hline 정치안정 & 8.0 & 20.3 & 57.1 & 11.3 & 26.9 & 7.1 & 18.4 & 9.9 \\
\hline 정부효율 & 9.5 & 5.7 & 13.3 & 18.6 & 47.1 & 56.2 & 26.7 & 2.4 \\
\hline 제도구축 & 19.5 & 1.9 & 9.0 & 3.8 & 28.1 & 57.1 & 5.7 & 1.4 \\
\hline 법 치 & 6.1 & 9.4 & 18.9 & 2.8 & 33.0 & 39.6 & 10.8 & 0.9 \\
\hline 부패방지 & 9.0 & 45.7 & 23.3 & 8.1 & 35.2 & 48.1 & 5.7 & 1.9 \\
\hline
\end{tabular}

자료 : World Bank

\section{(3) 엘리트레아}

세계에서 가장 빈곤한 국가로서 2009년 현재 1인당 국민소득이 336 달러이다. 2009년 현재 인간 개발지수(human development index)는 179 개국 중 165 번째이다. 2003년에 행한 가계조사와 참여 적 빈곤평가 보고서에 의하면 인구의 $2 / 3$ 가 빈곤선 이하에서 살고 있다. 에티오피아와 30 년 전쟁 후 에 이 나라는 1991년에 독립하게 되었다. 독립직후 수년 안에 기본적인 경제, 사회 인프라의 복구, 사회지표의 개선, 거시 경제적 안정과 경제성장 등으로 매우 인상적인 발전을 보여 주었다. 이러한 발전은 1998년에 에티오피아가 국경분쟁을 일으켜 분쟁이 재발되었다. 2000 년말 이래 유엔이 국경 선 획정을 중재해 오고 있으나 아직도 전쟁도 아니고 평화도 아닌 상태 하에 놓여 있다. 따라서 정부 는 고도의 동원태세로 남아 있으며 20만 명이 동원될 것으로 추정하고 있다. 이러한 상황 하에서 경 
제의 불균형을 타개할 여유가 없는 상태이다.

2009년 현재 이 나라는 모든 지표에 있어서 퇴보현상을 보여주고 있을 뿐만 아니라 시민 참여, 정 부효율성, 제도 구축 및 법치가 10 이하인 것이다. 한편 정치 안정(20.3)과 부패방지(45.7)는 약간 높은 편이나 1996년에 비하여 악화되고 있는 실정이다.

아프리카는 다른 지역에 비하여 국가 간 영토분쟁과 종족 분쟁 등 많은 분쟁을 안고 있는 지역이 며 거버넌스의 개선, 사회통합 및 문화통합의 많은 과제를 안고 있다. 전쟁내지 무력 분쟁은 모든 정 치, 경제, 사회활동에 우선순위를 가지게 됨으로 기타 모든 활동은 자연히 지연되게 된다. 전쟁의 부 정적인 측면을 재삼 실감하게 되며 발전의 저해요인임을 알 수 있다.

\section{(4) 벨라루스}

이 나라는 1991년 독립이후 다른 CIS국가와 유사한 문제에 직면하였다. 즉, (i) 계획경제로부터 시 장경제로의 이행, (ii) 정치적 의사결정과정의 개방, (iii)정부의 재정능력을 파괴하는 여건 하에서 기 본적 사회 서비스의 공급 계속 등을 들 수 있다. 벨라루스는 초기에는 유리한 외부 환경 하에서 제한 적이지만 충분한 개혁을 단행하였고 현저한 경제성장을 달성하였으며 다른 근린국가와는 달리 1 인당 소득의 심각한 감소를 피할 수 있었다. 이 나라는 CIS국가 중에서는 가장 높은 소득수준을 가진 나라 의 하나이며 빈곤율도 가장 낮은 편에 속한다. 2003-2008년간에 연 평균 경제성장률은 9 퍼센트에 달하여 1 인당 소득이 3 배 증가하였다. 이 지역에서 가장 높은 빈곤 감소율을 달성하였다. (World Bank, Belarus: Country Brief 2010)

2007년부터는 에너지보조금의 급격한 삭감과 해외시장에서 경쟁심화가 시작되었다. 따라서 금융 압박과 교역조건의 악화는 심화 되어 세계적인 금융 및 경제위기의 시작과 더불어 2008년에는 경제 여건이 더욱 악화되었다. 이러한 위기는 벨라루스의 구조적 가변성을 노출하게 되어 개혁의 필요성 이 급증한 반면에 거시 경제적 위험은 현저하게 남아 있다. 문제는 국내 및 해외의 경제적 상황의 변 화에 대응하는 동태적인 경제관리 내지 정책의 미비에 원인이 있는 것이다. 이는 효과적인 경제 거버 넌스의 확립과 그 운영의 실패에 기인하는 것이다.

이 나라가 당면한 개혁의 과제는 매우 크고 복잡하다. 그리하여 막대한 정부규제제도, 행정, 조세 및 지원 등으로 부터 나오는 다양한 경제적 혼란의 동시적인 개혁을 요구한다. 이 나라가 당면한 문 제는 확장적인 공공투자 주도의 성장으로부터 민간부문 주도의 생산성향상으로 이동해야 하는데 있 다. 이는 민간투자 특히 외국 직접투자를 증대시켜 새로운 기술이전을 지원하고 구조적 전환 과정을 촉진시키는데 있다.

2009년 현재 이 나라는 정치 안정이 가장 높을 뿐 그 이외 지표는 매우 낮은 편이다. 시민참여, 정 부효율, 제도 구축, 부패방지는 낮은 상태로 1996년 이래 아무런 개선이 없는 편이다. 법치는 오히려 퇴보하고 있다. 특히 시민참여(7.1), 정부효율(13.3)과 제도 구축(9.0)이 매우 낮고 아무런 개선이 없 는 것은 시장경제로 전환하였지만 경제운영방식은 과거의 사회주의방식의 주축을 그대로 유지하였기 
때문이다. 즉, 권위주의적 정부 하에서도 단기적으로 높은 성장을 할 수 있지만 장기적으로 지탱할 수 없다는 것을 여실히 보여 주었다.

\section{(5) 베네수엘라}

이 나라는 자연자원이 풍부하고 남미에서 가장 많은 석유 광물자원을 가지고 있는 나라 중에 하나 이다. 따라서 지속적인 경제 및 사회발전을 할 수 있는 막대한 잠재력을 가고 있는 나라이다. 2009 년 현재 1 인당 GNP는 7,320 달러로 높은 편이다. 그러나 빈곤은 아직 정부의 주요 도전과제인 것 이다. 과거 20 년간에 걸쳐 이 나라는 매우 심각한 정치, 경제 및 사회적 혼란을 경험하였다. 카리스 마가 있고 인기주의자인 좌파의 Chavez 대통령은 광범위한 개혁, 헌법 개정과 주요 기간산업의 국유 화를 약속하고 있다. 그의 프로그램은 빈곤층을 돕는데 주안점을 두어 무료건강진료, 식품보조와 토 지개혁 등을 포함하고 있는데 대부분 1인당 소득 증대로 1995-2005년간에 빈곤을 30퍼센트 감소시 켰다. 같은 기간에 극빈인구를 인구의 32 퍼센트에서 19 퍼센트로 감소시켰다. 그러나 빈곤율은 가변 적인 경제성장으로 변동이 많다.

베네수엘라의 사회는 현대통령의 개성과 통치방식에 따라 매우 다원화되어 있다. 그는 인기 있는 계층으로부터는 강력한 지지를 받는 반면에 엘리트와 중산층은 쿠바식 권위주의적 정부를 원하는 그 를 반대하고 있다. 그의 오랜 집권기간 중 그는 쿠데타, 시위, 파업, 시민 불안과 점증적인 반대에 직면하고 있다. 국민은 2007년에 그의 권력을 연장하고 사회주의적인 개혁을 가속화시키는 제안을 반대하였다. 그러나 그 후에 국민은 Chavez 대통령이 2012년에 재선출마를 하는 길을 열어준 2009 년 개헌안에서 임기제한을 폐지하는 선거에서 대통령을 지지하였다.

베네수엘라의 경제적 행운은 세계 석유가격과 관련이 깊다. 석유는 국제무역에 있어서 비교우위를 베네수엘라에 주고 있다. 석유는 국내경제의 균형을 깨고 있다. 왜냐하면 석유는 GDP의 30 퍼센트 이상을 차지하며 총수출의 90 퍼센트와 재정수입의 50 퍼센트를 차지고 있기 때문이다. 그는 사회프 로그램을 축소시키지 않을 것을 선언하였으며 정부는 국유화 아젠다를 계속 밀고 나갈 것이다. 그리 하여 The Bank of Venezuela(Santander Group), 고속도로제도, Sidor(Algentin의 Ternium이 소 유한)과 시멘트공장 Holim과 Lafarge 등을 이미 국유화 하였다. (World Bank, Venezuela: Country Brief 2010)

2009년 현재 거의 모든 거버넌스 지표가 악화되고 있다. 시민참여(26.1)가 가장 높으며 민주주의 의 척도로서 1996 년의 51.2 에서 26.1로 악화일로를 걷고 있다. 나머지 정치안정(11.3), 정부효율 (18.6), 제도 구축, 법치 및 부패방지는 1996년 이래 계속 악화되고 있다. 특히 제도 구축(3.8), 법치 (2.8) 및 부패방지(8.1)는 최하위 권으로 10미만이다. 현재 유지하고 있는 경제발전은 국제석유가격 의 혜택이지 거버넌스의 개선과는 아무런 연관성이 없다. 
(6) 가이아나

이 나라는 남미에서는 수리남과 우루과이 다음으로 세 번째로 가장 작은 나라이다. 인구도 1 백만 명 이하이다. 가이아나는 역시 중남미에서 아이티와 니카라과 다음으로 세 번째로 가난한 나라이다. 이 나라는 1 인당 GNI가 1,450 달러이지만 건전한 정책으로 최근에는 매우 견고한 거시 경제적 실적 을 기록하였으며 2007-2010년간에 연간 성장률이 4 퍼센트 정도이다. 세계적인 금융위기는 이 나라 에도 영향을 미쳤지만 중남미의 다른 나라에 비하여 심각한 정도는 작은 편이다. 소비의 불평등은 비 교적 심하지 않지만 전국적으로 볼 때 지리적 지역, 교육수준 및 인종 간에는 커다란 불균형을 노정 하고 있다. 1999-2006년간에 빈곤율은 거의 정체상태에 있다. MDG의 진척도를 보면 이 나라는 기 아, 교육과 환경면에는 목표달성이 가능한 것으로 보이나 빈곤, 아동 사망률, 모성보건과 주요 질병 은 목표를 달성하지 못할 것으로 보인다. 이 나라의 성장을 위한 당면 과제는 환경의 보호와 관리, 인프라의 개선, 교육의 질의 향상, 보건의 질적 향상, 거버넌스의 개혁과 국가의 근대화 등을 열거 할 수 있다. (World Bank, Guyana: Country Brief 2010)

2009년 현재 가이아나의 거버넌스 지표를 보면, 시민참여(51.7)와 정부효율(47.1)은 높은 편이지 만 정치 안정(26.9), 제도 구축(28.1), 법치(33.0) 및 부패방지(35.2)는 비교적 낮은 편이다. 특히 정 부효율과 부패방지를 제외하고는 나머지 지표는 1996년에 비하여 악화되고 있다.

\section{(7) 우즈베키스탄}

중앙아시아의 우즈베키스탄은 1991년 독립 후에 다른 CIS국가들과 달리 시장경제에로의 점진적인 접근방법을 채택하였고 국가주도하의 개발정책은 수입대체공업화정책 내지 지방화 정책, 에너지 및 식량자급정책을 고수하고 있다. 이러한 정책은 다른 CIS 국가들이 경험하는 것보다 경제적 사회적 고통/충격은 작지만 발전의 속도는 매우 완만하다. 전반적인 거버넌스 지표는 정치적 안정(18.4)과 정부의 효율성(26.7)을 제외하고는 매우 낮은 수준을 보여주고 있다. 2009년 현재 시민참여, 정치안 정, 법치, 부패방지는 오히려 퇴보현상을 보여주고 있다. 낮은 수준의 시민의 참여(2.4), 법치(10.8), 제도 구축(5.7) 및 부패방지(5.7)는 발전의 전반적 토대가 형성되어 있지 않음을 여실히 보여 주고 있다. 우즈베키스탄의 발전의 장애는 제도적인 기반구축과 개방, 경쟁적인 시장경제로 이행해야 하 는 것이 급선무이다.

\section{(8) 콜롬비아}

다른 중남미국가들이 소득불평등, 빈곤 및 내전 등과 싸우고 있는 있지만 중남미의 콜롬비아는 위 의 세 가지 문제와 동시에 싸우지 않을 수 없는 국가이다. 2003년 정부군과 협상결과 게릴라 집단은 집단무장해제를 하여 평화가 찾아온 줄 알고 있었는데 아직도 불법 무장 세력이 많은 것이다. 따라서 과거 7년간에 이주민이 160 만 명에 달한다고 한다. Santos대통령은 전임자가 쌓아 놓은 안보 및 경 
제여건을 바탕으로 게릴라 없는 콜롬비아 건설, 부정부패척결을 통한 투명성제고, 정치 및 사법개혁 을 정책과제로 내세우고 있다. 빈곤은 평화와 소득불평등과 더불어 이 나라가 당면한 주요과제이다. 2009년 현재 전반적인 지표에 있어서 매우 현저한 개선을 보여주고 있으며 특히 시민참여(42.7), 정 부효율성(56.2), 제도 구축(57.1) 및 부패방지(48.1) 등의 분야에서 탁월한 개선을 보여주고 있다. 그 러나 아직도 정치안정(7.1)과 법치(39.6) 면에서 개선의 여지가 있다. 전반적으로 다른 개도국에 비 하면 상술한 세 가지 과제에 도전하는 국가로서 매우 양호한 실적을 보여준 편이다.

이상의 16 개국의 거버넌스의 비교분석을 통하여 거버넌스는 발전에 크게 영향을 미치고 있음을 알 수 있으며 거버넌스 개혁을 통하여 거버넌스를 개선함으로서 발전을 도모할 수 있음을 알 수 있다. 물론 거버넌스의 지표는 상술한 지표 이외에 다른 지표도 많다. 특히 country-specific study를 하 는 경우에는 더욱 그러하다. ${ }^{8)}$ 공통적인 지표를 선정하여 cross-country analysis를 하는 경우에는 국가 간 비교분석에는 적합하지만 country-specific study에는 각국의 특수한 지표가 누락되어 당 해국 연구의 참다운 분석결과를 얻지 못하게 되는 경우도 있음을 명심해야 한다. (Yasutami, 2005)

결론적으로 말하면 성공사례국들은 민주주의 수준이 높고 정부의 효율성, 제도 구축, 법치 및 부 패방지 면에서 실패사례국보다 우수하다는 것을 알 수 있다. 성공 사례국 중 중국과 싱가포르를 제외 한 다른 국가들은 (인도를 제외하고) 대체로 권위주의적 정부의 경험을 거친 후에 민주화과정을 거친 국가들이다. 반면에 실패 사례국들은 가이아나와 콜롬비아를 제외하고는 거의 모든 국가들이 권위주 의적인 국가나 대리민주주의국가들이다.

\section{V. 요약 및 결론}

1. 과거 수십 년간 세계를 휩쓸었던 민주주의와 시장경제로의 이행은 모든 국가들이 경제발전, 정 치 및 사회통합의 요구와 발전의 과실의 공평한 분배에 대한 대중의 요구에 동시적으로 대처하 지 않으면 아니 되었다는 것을 말한다. 이러한 도전에 효과적으로 대응할 능력은 대체로 각국의 제도적 부존기반(institutional endowment)에 달려 있다. 이러한 제도적 부존기반을 구축하고 강화하는 것은 양호한 거버넌스가 전제조건이다. 왜냐하면 지속적인 경제발전은 양호한 거버넌 스 없이는 불가능하기 때문이다. 공개적이고 경쟁적인 시장의 효과적인 거버넌스는 재산권, 법치와 적절한 규제를 필요로 한다. 그러한 제도적 발전은 민주발전과 결합되어 있으며 일반적 으로 폐쇄된 권위주의적 제도와는 맞지 않는다. 권위주의 제도 하에서는 단기적인 성장을 기대

8) UNDP(2004) UNDP National Human Development Report(NHDR) and The Use of Democratic Governance Indicators(ed. by J. Nahem)와 UNDP(2010) Governance Indicators: A Using Guide, 2nd. ed. 는 국별 연구를 위해 서는 매우 유용한 문헌이다. 
할 수 있으나 장기적으로는 매우 가변적이며 미래의 장기적인 지속성장의 기반을 훼손시킨다.

2. 제도적 관심은 거시적 개혁뿐만 아니라 미시적인 정책과 규제에도 세심한 주의를 기울여야 한 다. 또한 제도적인 발전은 경제발전과 정치발전정책의 통합된 접근방법을 요구하고 있다. 만약 제도개혁이 거버넌스의 기본원칙을 잘 준수한다면 제도개혁은 공적 거버넌스와 시장경제촉진 에 도움을 줄 수 있다.

3. 개혁을 수행함에 있어서 민주주의와 시장경제 중 민주주의에 우선순위를 두지 말고 시장경제와 민주주의를 동시에 지원할 수 있는 거버넌스 제도개혁에 우선적으로 주의를 경주해야 한다.

4. 다음으로 양호한 거버넌스는 인권신장과 시민자유의 보호에 관건이 될 뿐만 아니라 경제발전과 생활수준을 향상하는 잠재력과 깊은 상관관계에 있다. 많은 개도국들(특히 취약국가와 분쟁 후 국가 등)은 그들의 거버넌스의 질을 개선하고 있지만 아직 계속 개선할 필요와 책무가 있다. 그 러나 선진제국과 국제개발협력기구도 특히 취약국가와 분쟁 후 국가들에 대하여 양호한 거버넌 스를 증진시키는데 협력을 해야 할 것이다.

5. 만약 국민은 시장경제를 통하여 가시적인 이익을 받지 못하면 민주주의는 지탱될 수 없다. 바꾸 어 말하면, 민주주의는 국민에게 정치적 자유 및 경제적 이익을 제공해야 한다. 민주적 거버넌 스는 이를 가능하게 만드는 장점을 지니고 있다. 민주적 거버넌스 제도는 지속적인 경제발전과 높은 수준의 민주주의를 결정하는 것이다. 민주적 거버넌스는 그자체가 매우 값진 것이다. 민주 적 거버넌스는 인간개발에 도움을 주고 있다. (UNDP, 2002, p.13) 민주적 거버넌스의 개선은 지속가능한 성장을 촉진을 지원하는 것이다.

6. 거버넌스와 발전을 연결시키는 데는 원칙적으로 어떤 일반적 결론을 내릴 수 있다. 그러나 민주 적인 거버넌스의 규범적 원칙은 인정하면서 국가마다 다른 발전경로를 밟고 있다. 따라서 이러 한 범위를 넘어 모든 국가에 적용할 수 있는 제도적 장치에 대한 단일모형은 존재할 수 없는 것 이다. 세계의 각국은 각기 다른 정치, 경제, 사회, 및 문화적 여건 하에서 살고 있기 때문에 단 일의 제도적 장치는 있을 수 없는 것이다. 제도의 발전은 개도국 내부에서 주도되어야 하며 국 내사정을 감안하여 우선순위를 결정해야 한다. 경제발전에는 많은 상이한 길이 있는 것이다.

7. 민주주의와 발전은 상호작용을 하지만 민주주의는 경제발전을 위하여 결정적인 요소로 남아 있 다. 민주주의는 발전의 테두리 안에서 본질적이고 유효한 수단이다. 특히 민주화의 문제는 발 전을 위하여 매우 중요한 것이다. 많은 개도국에 있어서 민주주의의 출현과 통합의 주요 장해요 인은 미개발이 아니라 저개발(underdevelopment)상태이다. 이것이 해결해야할 전제조건인 것 이다. 다양한 장해요인으로는 낮은 소득수준과 교육수준, 소득 및 정부지출의 불평등, 다양화 하지 않은 경제, 정치 및 사회구조, 식민지 유산 등을 들 수 있다. 또한 민주화의 전제조건으로 서 경제개발의 중요성을 강조하는 학자(S. Lipset 등)도 있다. 경제정책과 개혁은 민주화를 촉 진시키는데 필요하다는 것이다. 경제발전은 성장, 생활수준의 향상, 보다 나은 사회서비스와 빈곤감소 등을 가져오는 과정이라는 것이다. 하여간 정치적 접근방법과 경제적 접근방법은 통 
합되어야 한다.

8. 민주주의와 경제발전은 전반적인 거버넌스 제도에 따라 좌우되며 민주주의는 정치적 거버넌스 에 의하여, 경제발전은 경제적 거버넌스에 의하여 각각 영향을 받는다. 결국 이러한 거버넌스 는 민주적 거버넌스건 권위주의적 거버넌스건 간에 제도적 발전 내지 개혁이 관건인 것이다. 이러한 제도적 질은 역량개발 여하에 달려 있다. 이러한 역량개발은 개인수준, 조직수준 및 사 회적 수준에서 진행된다. (김달현, 2010, pp. 51-52) 이러한 사회적 수준의 능력이 바로 국가역 량(state capacity)을 말하는 것이다. 결국 개도국자체의 국가의 총체적 역량개발을 위해서는 우선 개도국 주도의 제도발전이 추진되어야하며 제도발전은 상술한 세 가지 수준의 역량개발에 달려 있다는 것이다.

9. 경제적(경제성장), 사회적(사회적 동원) 및 정치적 변수(민주주의, 국가구축, 법치)가 있는 경우 에는 5 개 중 어느 하나도 출발점이 될 수 있다는 것이다. 즉, 발전전략의 입안자들에게는 많은 선택의 여지가 있으므로 전략의 선택은 각 개도국의 역사적 사정에 따라 결정해야 할 것이다. 따라서 그들의 출발점은 각국에 따라 상이하며 우선순위의 결정도 각 개도국의 특수한 사정에 에 따라 행해야 될 것이다. 이러한 순환론적 입장에서 개도국이 중요한 측면을 선정하여 출발점 으로 삼아야 할 것이다. 


\section{참고문헌}

\section{1. 국내문헌}

김달현(2011) “거번넌스와 개발”, 국제개발협력 이슈, 한국국제협력단, pp. 116-162

김달현(2009) “발전과 양호한 거버넌스”, 국제개발협력연구, 국제개발협력학회, 1(1), pp. 27-66

김달현(2010) “발전과정에 있어서 제도개혁의 역할과 역량개발", 국제개발협력연구, 국제개 발협력학회, 2(2), pp. 51-52

\section{2. 국외문헌}

Ahrens, J.(2002) Governance and Economic Development: A Comparative Institutional Approach, Edgar

Barro, R.(1999) "Determinants of Democracy", Journal of Political Economy, 107(6) 158-183

Barro, R.(1996a) "Democracy and Growth", Journal of Economic Growth, 1(1) 1-27

Barro, R.(1996b) "Determinants of Economic Growth: a cross-country empirical study", NBER Working Paper No. 5698

Bettcher, K.E. and Shkolnikov, A.(2009) Democratic Governance and the Quality of Growth, Center for International Private Enterprise, pp.4-5

Branco, M.C.(2006) The Political Economy of Democratic Governance and Economic Development, Economics Working Papers, University of Evora, p.3

Dahl, R(2000) On Democracy, New Haven: Yale University Press, p. 191

Dalton, R. J and Ong, N.T.(2005) "Authority Orientations and Democratic Attitudes: A Test of the 'Asian Value' Hypothese", Japanese Journal of Political Sciences, 6(2) 1-21, p.1

Desta, A(2010) Transitional Democratic Governance and Economic Development: The Ethiopian Experience, http:tigraionline.com/democratic-governance.html: (검색일: 2011. 7. 24.)

El-Makawy, N and Oia, I.(2009) Understanding and Programming For Linkage: Democratic Governance and Development, Discussion Paper 8, Oslo Governance Centre.

Fitoussi, J.P.(2004) La Democratie et le Marche, Paris: Grasset

Goldsmit(1995) "Democracy, Property Right and Economic Growth", Journal of Development Studies, 32(2): $71-85$

Habiso, T.(2011) "The Challenge of Implanting and Building Multi-Party Democracy in Multi- 
Ethnic Societies" http://aigaforum.com/articles/The_Challenge_Building_Multiparty.htm(검색 일: 2011. 7. 24.)

Halperin, Siegle and Wein Stein.(2005) The Democracy, Advantage: How Democracies Promote Prosperity and Peace, New York: Routledge

Holz, M \& Kim, B.J.(ed.) (2002), Building Good Governance: Reforms, Seoul.

Kaufmann, D., Kray, A., Zoido-Lobaton,P(1999) “Governance Matters", Policy Reasearch Working Paper No. 2196. Washington: The World Bank

Klein Peter G.(1998) New Institutional Economics, http://www.papers.sem.com/so13/papers.cfm? abstract-id(rjatordlf, (검색일: 2010. 10. 10.)

Kofi, T.A and Desa(2008) The Saga of African Underemployment: A Viable Approach for Africa's Sustainable Development in the $21^{\text {st }}$ Century, 2008, Trenton, N. J: Afric World Press. p. 320

Leftwitch, A.,(1994) Governance, Democracy and Development in the 3rd World,

Leftwich, A. (2000) States of Development, Cambridge: Polity.

Lipset, S. M.(1963) Political Man, New York: Anchor Books, p.31

Lipset,S.M(1959) "The Social Requisites of Democracy: Economic Development and Political Legitimacy", American Political Science Review, 53: 69-105

Mitchell, R.E.(2011) How to Link Democratic Governance with Economic Growth. pp. 8-9. http://www.unc.edu/depts/diplomat/AD_9/mitchell.htm! (검색일: 2011. 07. 24.)

North, D.(2004 [1990]) Institutions, Institutional change and Economic Performance, Cambridge UK, Cambridge University Press

ODI(2006) "Governance, Development and Aid Effectiveness: Quick Guide to Complex Relationship", Briefing Paper, Overseas Development Institute, UK

Olson, M.(1993) "Dictatorship, Democracy and Development," American Political Science Review, 87 (3): $567-576$.

Pastor, M and Hilt, E.(1993) "Private Investment and Democracy in Latin America", World Development, 21: 489-50

Pei, M.(1999) "Economic Institutions, Democracy, and Development," paper presented at the World Bank Conference on Democracy, Market Economy, and Development, pp.26-27; available online at www.carnegieendowment.org/publications/index.cfm? $\mathrm{fa}=$ print\&id $=66$

Perkins D., Rade, S., \& Lindauer, D.(2006) Economics of Development, 6 ${ }^{\text {th }}$ ed., W.W. Norton, pp. $82-84$

Przeworski, A., Alvarez, M., Cheilub, J. A. and Limongi, F.(2000) Democracy and Well Being in the World 1950-1990, New York: Cambridge University Press.

Przeworski, A., Alvarez, M., Cheilub, J. A. and Limongi, F.(1996) "What Makes Democracies 
Endure," Journal of Democracy, 7 (1): 39-55.

Przeworski, A., Limongi, F.(1993) "Political Regimes and Economic Growth," Journal of Economic Perspectives 7 (3): 51-69.

Przeworski, A., Meseguer, C.(2006) "Globalization and Democracy." in P. Bardhan, Bowles, S. and Wallerstein, M. (eds), Globalization and Egalitarian Distribution. Princeton: Princeton University Press, pp 169-191.

Rodrik, D.(1997) Democracy and Economic Performance, Harvard, available online at ksg.harvard.edu/ rodrik/demoecon.PDF

Sen, A. K.(1999a) “Democracy as a Universal Value," Joumal of Democracy, Vol. 10, No.3, p. 10.

Sharma, S. D.(2007) Democracy, Good Governance, and Economic Development, Taiwan Journal Of Democracy, Vol. 3, No.1:29-62, p.31-33

Singapore-Economc Development, http://Singapore-ECONOMIC-DEVELOPMENT.html\#ixzz1TELITitZ

Turner, K.(2011) "The Importance of Good Governance in Achieving Economic Growth for

Developing Nations: Analysis of Sub-Saharan Africa”, Bryant Economic Research Paper Vol. 4, No. 4

Udoh, E and Udeaja, E.A.(2011) "Ten Years of Industrial Policies under Democratic Governance in Nigeria: New Wine in Old Bottle", European Journal of Social Sciences, Vol. 20. No.2

\section{UNDP(2011)Democratic Governance}

http://www.undp.org/governance/about_us.shtml. (검색일: 2011.8.5)

UNDP(2010) Governance Indicators: A Using Guide, 2nd. ed.

http://www.undp.org/siyes/default/files/undp_users_guide-online_version.pdf (검색일: 2010.

UNDP(2006) Governance for the Future: Democracy and Development in the Least Developed Countries

UNDP(2004) UNDP National Human Development Report(NHDR) and Use of Democratic Governance Indicators, edited by J. Nahem

UNDP(2002) Human Development Report: deepening democracy in a fragmented world, Oxford: Oxford University Press, p. 13

UNDP(1997) "Governance for Sustainable Human Development", A UNDP Policy Paper

Wade, R.(1990) Governing the Market: Economic Theory and the Role of Government in East Asian Industrialization, Princeton University Press World Bank(2011a) Brazil: Country Brief http://web.worldbank.org/WEBSITE/EXTERNAL/COUNTRIES/LACEXT/BRAZILE... (검색일: 2011. 7.31)

World Bank(2011b) Belarus: Country Brief 2010 
http://web.worldbank.org/WEBSITE/EXTERNAL/COUNTRIES/ECAEXT/BELARU (검색일: 2011. 7.31)

World Bank(2011c) Chile: Country Brief 2010 http://web.worldbank.org/WEBSITE/EXTERNAL/COUNTRIES/LACEXT/CHILEEX... (검색일: 2011. 7.31)

World Bank(2011d) China Overview http://worldbank.orglen/country/china/overview.print (검색일: 2011. 7.31)

World Bank(2011e) Cote d'Ivoire: Country Brief http://web.worldbank.org/WEBSITE?EXTERNAL/COUNTRIES/AFRICAEXT/CDIV... (검색일: 2011. 7.31)

World Bank(2011f) Eritrea: Country Brief http;//web.worldbank.org/WEBSITE/EXTERNAL/COUNTIRES/AFRICAEXT/ERIT... (검색일: 2011. 7.31)

World Bank(2011g) Guyana: Country Brief 2010 http://worldbank.org/WEBSITE/EXTERNAL/COUNTRIES/LACEXT/EXTGUY.. (검색일: 2011. 8.5)

World Bank(2011h) India Country Overview September 2010 www.worldbank.org.in/WEBSITE/EXTERNAL/COUNTRIES/AOUTHASIAEX... http://www.worldbank.org.in/WBSITE?EXTERNAL?COUNTRIES?SOUTHASIAE (검색일: 2011.8.5)

World Bank(2011i ) The Republic of Korea: County Brief, http://web.worldbank.org/WEBSITE?EXTERNAL/COUNTRIES?EASTASIAPASIFI (검색일: 2011. 7.31)

World Bank(2011j) Venezuela: Country Brief 2010 http://web.worldbank.org/WEBSITE/EXTERNAL/COUNTRIES/LACEXT/VENEZU... (검색일: 2011. 8.5)

World Bank(2011k) Zimbabwe: Country Brief 2010 http://web.worldbank.org/WBSITE/EXTERNAL/COUNYTRIES/AFRICAEXT/ZIMB.. (검색일: 2011. 8.6)

World Bank(2011k) World-wide Governance Indicator database

World Bank(2009a) "Beyond Economic Growth: Meeting the Challenge of Global Development", Chapter 1. http://www.worldbank.org/dep/web/beyond/global/chapter1.html. (검색일: 2009. 7.4.) 
World Bank(2009b) "Governance Matters 2009: Release of Worldwide Governance Indicators 1996-2008"

World Bank(2008) Governance, Growth, and Development Decision-making

World Bank(1991) The Challenge of Development, World Development Report 1991, Oxford University Press, p.4

Yasutami, Shinomura(2005), "The Role of governance in Development Revisited: A Proposal of an Alternative View", FASID 